This work is licensed under Creative Commons Attribution 4.0 International (CC BY 4.0). [http://creativecommons.org/licenses/by/4.0/]

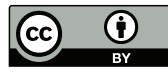

\title{
Kierunki działań dyplomacji Rzeczypospolitej Obojga Narodów w latach 1569-1589 - próba analizy
}

Marcin Janakowski | Uniwersytet Marii Curie-Skłodowskiej w Lublinie, Wydział Humanistyczny https://orcid.org/0000-0002-1578-3859

Słowa kluczowe:

Zygmunt II August, Henryk Walezy, Stefan Batory, dyplomacja, legacje, poselstwo, Rzeczpospolita Obojga Narodów

\section{Streszczenie}

Pierwsza Rzeczpospolita, jako efekt porozumienia, unii dwóch różnych narodów, była z całą pewnością wyjątkowym projektem w dziejach Europy. Funkcjonowanie nowego organizmu państwowego musiało opierać się na współpracy i wzajemnych kompromisach, także w odniesieniu do kwestii polityki zagranicznej. Prowadzenie wspólnej dyplomacji stało się nie tylko przywilejem, ale także obowiązkiem klasy politycznej drugiej połowy XVI wieku.

Poziom trudności tego zadania ujawnił się już w roku 1572, kiedy wraz ze śmiercią ostatniego Jagiellona polityka Rzeczypospolitej musiała współistnieć z bieżącymi aspiracjami i planami kolejnych królów elekcyjnych. Pojawiające się rozbieżności najlepiej obrazował czas panowania Henryka Walezego, który skupiony na wydarzeniach w rodzimej Francji, niemal wygasił polsko-litewską dyplomację na blisko trzy lata. Elekcja, a następnie panowanie Stefana Batorego wiązało się z przeznaczeniem niemal wszystkich sił na prowadzenie polityki wschodniej i dbanie o możliwe najlepsze relacje z Imperium Osmańskim. Lata 1587-1589 to z kolei czas walki o władzę w Rzeczypospolitej, ale także czas próby wygaszenia wewnętrznych konfliktów poszczególnych stronnictw politycznych.

Wszystkie te wydarzenie bardzo mocno oddziaływały na kierunki polityki zagranicznej i determinowały obszar aktywności dyplomatycznej Rzeczypospolitej. Celem niniejszego artykułu jest wskazanie tych kierunków, analiza intensyfikacji podejmowanych misji w określonym czasie, a następnie próba zestawienia ich z bieżącymi działaniami politycznymi. Będzie to więc próba zaobserwowania pewnych prawideł, właściwych dla dynamicznie zmieniającego się okresu pierwszych dwóch dekad po Unii Lubelskiej. 


\section{Directions of diplomacy of the Polish-Lithuanian Commonwealth in the years 1569-1589 - an attempt at analysis Summary}

Keywords: Polish-Lithuanian Commonwealth as result of union of two different countries, was phenomenon in European history. Cooperation and compromises in foreign policy were fundamental for activity of new state. Common diplomacy was duty of political elites of second half of XVI century.

Real difficulties began with death of last king of Jagiellonian dynasty in 1572. Policy and intentions of election kings had to coexist with reason of state of Commonwealth. It was not easy. Henry's de Valois times showed that king was more interested in situation in France than Poland. It caused extinction of Polish diplomacy for 3 years. In Batory's times almost all power was concerted in east policy. Good relations with Ottoman Empire was also very important for this king. 1587-1589 was time of fighting over Polish crown. It was also time of efforts of gain of stabilisation in state.

The directions and activity of Polish diplomacy were depended by all these events. The purpose of this article is presentation of diplomatic directions and intensification of diplomatic missions in various areas. It is an attempt to present some principles appropriate for the dynamic period of the first two decades after the Union of Lublin, I hope that it is successful.

\section{Wstęp}

Niewątpliwym osiągnięciem polskiej historiografii jest sytuacja, w której wiedza badaczy na temat historii politycznej naszego kraju wydaje się stosunkowo pełna. Pewnego rodzaju "białe plamy" odnoszą się jedynie do czasów przedpiastowskich, kiedy ilość pozostawionych źródeł, szczególnie źródeł pisanych, jest tak niewielka, że uniemożliwia dogłębne poznanie minionej rzeczywistości. Zdają się to potwierdzać kwerendy archiwalno-biblioteczne, prowadzone przez rzeszę naukowców w kraju i poza granicami. Ich efekty pozwalają przypuszczać, że spektakularne odkrycia w zakresie historii politycznej są dzisiaj mało prawdopodobne. Zdecydowanie pewniejsze jest założenie, że rozwijająca się nauka pozwoli uszczegółowić posiadaną wiedzę, a następnie poddać pewne utarte twierdzenia reinterpretacji. Aktualizacja stanu badań pozwala także przedstawić określony problem w innych perspektywach badawczych, wcześniej niezauważanych z powodu innych priorytetów poznawczych.

Takim samym regułom podlegają badania nad dziejami i funkcjonowaniem dyplomacji w różnych okresach historycznych. Rozprawy naukowe traktujące o powyższej tematyce odnoszą się w przeważającej mierze do politycznego wymiaru relacji międzynarodowych, rzadziej społecznego lub kulturowego (Biskup 1980; Dopierała 1986; Dziubiński 2005; Henning 1987; Nowak-Kiełbikowa, Bułhak, Wójcik 1993; Nowek 1992; Wijaczka 1998; Wojtyska 1977; Wójcik 1982). Badaniom poddawane są zwykle efekty działań 
dyplomatycznych, korespondencja, instrukcje poselskie, traktaty, relacje czy diariusze. Wydaje się jednak, iż w oparciu o istniejący zasób źródłowy oraz dostępną literaturę przedmiotu można pokusić się też o inne o spojrzenia na wspomnianą tematykę.

Działania dyplomatyczne, jako pozamilitarny sposób realizowania szeroko rozumianej polityki, mają swoje określone cele oraz wyznaczone kierunki. Analiza misji dyplomatycznych i zestawianie ich założeń z osiąganymi efektami to właściwie badania nad skutecznością polityki zagranicznej lub umiejętnościami dyplomatycznymi posłów i ich mocodawców. Rozważania te stanowią podstawę do badań nad relacjami międzynarodowymi i ogólną polityką poszczególnych państw. Drugim elementem działań dyplomatycznych jest ich kierunek, czyli określenie adresatów lub obszarów działań dyplomatycznych, wskazanie intensywności realizowanych legacji i czas potrzebny do ich wykonania. Nieodzownym elementem badań nad celami i kierunkami działań dyplomatycznych jest ich wymiar personalny, rozumiany jako motywy doboru poszczególnych osób do realizacji misji poselskiej na określonym obszarze. W perspektywie mogłoby to doprowadzić do sporządzenia portretu zborowego dyplomatów Rzeczypospolitej, co pozostaje dziś istotnym postulatem badawczym.

W niniejszym artykule pragnę jednak skupić się przede wszystkim na analizie kierunków aktywności dyplomatycznej Rzeczypospolitej Obojga Narodów w latach 15691589 , wskazując tym samym obszar jej ofensywy dyplomatycznej i zachodzące w tej materii zmiany, wynikające z perturbacji politycznych wskazanych dekad. W związku z tym podstawowym celem pracy jest próba odpowiedzi na pytanie o stosunek aktywności dyplomatycznej Rzeczypospolitej do poszczególnych wydarzeń politycznych, takich jak otwarte konflikty zbrojne, zagrożenia ze strony państw ościennych, przedsięwzięcia międzynarodowe czy zmiany wewnątrz państwa.

Należy w tym miejscu zaznaczyć, iż nie będzie to ogólny obraz relacji dyplomatycznych Rzeczypospolitej, gdyż świadomie zostały pominięte kontakty inicjowane przez obce państwa, dwory, które stanowią zdecydowaną część szeroko pojętych stosunków międzynarodowych. Częste korzystanie z obecności przedstawicieli, posłów obcych państw i przekazywanie za ich pośrednictwem oficjalnej korespondencji czy mniej formalnych informacji nie może być, w moim przekonaniu, traktowane jako aktywna działalność dyplomatyczna. Inaczej również należy traktować misje mające bardziej „ambasadorski” niż poselski charakter, jak trwające kilka lat legacje Stanisława Hozjusza w Rzymie, Stanisława Kłodzińskiego w Neapolu czy Piotra Dunin Wolskiego w Madrycie (Biskup 1980: 721-723; Kot 1928: 1-24; Kalinowska 1992:V-XIV). Także na dworze cesarskim przez długi okres przebywali polscy przedstawiciele. W latach 1558-1564 był nim Marcin Kromer, następnie w latach 1565-1568 Franciszek Krasiński, wówczas sekretarz królewski i kanonik krakowski, oraz Łukasz Podoski, prepozyt gnieźnieński, który bawił tam od 1568 do 1572 roku (Żelewski 1983: 171-173; Barycz 1970: 319-325; Rocznik Służby Zagranicznej Rzeczypospolitej Polskiej według stanu na 1 kwietnia 1938, 1938: 42). Analizie zostały zatem poddane jedynie "doraźne" misje poselskie inicjowane przez uprawione organa Rzeczypospolitej. 


\section{Prawo a praktyka}

W przypadku omawianego okresu prawne umocowanie do prowadzenia polityki zagranicznej, wobec tego i dyplomacji, nie było kwestią jednoznacznie określoną. W wyniku tradycyjnego modelu ustroju społecznego polityka międzynarodowa w znacznej mierze utożsamiana była z polityką dynastyczną. W praktyce określał ją monarcha, przy większym lub mniejszym wsparciu doradców czy rady królewskiej. Dopiero kształtujący się w Królestwie Polskim parlamentaryzm przekazał część prerogatyw w ręce senatu oraz sejmu. Warto jednak zaznaczyć, iż w okresie panowania dynastii Jagiellonów polityka zagraniczna prowadzona była w imieniu króla i to on był rzeczywistym mocodawcą wysyłanych legacji. Pewne zmiany zaszły w związku z zawartą w 1569 roku Unią Lubelską, której 9 punkt określał zasady zawierania traktatów międzynarodowych, czy wysyłania poselstw do obcych państw: „Foedera aut pacta abo zmowy i przymierza z postronnemi narody wedla spolnej zgody warszawskiej na potym żadne czynione ani stanowione, żadni tyż posłowie w rzeczach ważnych do obcych stron posyłani być nie mają, jedno za wiadomością i radą spolną obudwu narodow, a przymierza albo stanowienia z ktorymkolwiek narodem przedtym uczynione, ktoreby były szkodliwe ktorej stronie, dzierżane być nie mają.[!]" (cytat za: Kutrzeba, Semkowicz 1932: 281) Zapis ten wykluczał właściwie samodzielną politykę monarchy w imieniu Rzeczypospolitej, choć w praktyce działania Zygmunta II Augusta zbliżone były do tradycyjnego modelu prowadzenia spraw zagranicznych (Przyboś, Żelewski 1959: 29-30).

Śmierć ostatniego Jagiellona i wybór monarchy w drodze wolnej elekcji istotnie zmieniły status realizowanej polityki zagranicznej. Każdorazowo zaprzysięgane Artykuły henrykowskie oraz pacta conventa zmniejszały formalną samodzielność monarchy w zakresie prowadzenia dyplomacji. Na mocy powyższych ustaw prawo zatwierdzania umów międzynarodowych i wypowiedzenia wojny powierzono kompetencji senatu. Sejm zaś miał prawo wysyłania w imieniu Stanów Rzeczypospolitej tzw. posłów wielkich, którzy reprezentowali majestat Rzeczypospolitej, nie zaś samego monarchę. Ten zaś miał prawo do wysyłania „posłów mniejszych", a i to za wiedzą senatu. Podział ten nie odnosił się jednak do wagi czy kierunków wysyłanych poselstw. Wykorzystywany był raczej do nadania potrzebnego splendoru realizowanej legacji, kiedy była taka potrzeba (Przyboś, Żelewski 1959: 30-32). W związku z tym w niniejszym artykule rozbieżności te nie będą odgrywały istotnej roli w określeniu kierunków działań dyplomatycznych.

Także w wymiarze praktycznym państwo polsko-litewskie nie odbiegało zasadniczo od norm właściwych dla świata zachodniego. Prowadzeniem polityki zagranicznej w wymiarze technicznym zajmowała się kancelaria koronna i litewska. Sprawiało to, iż kanclerz wielki korony oraz litewski pełnili rolę ministrów spraw zagranicznych, nieformalnie dzieląc między sobą obszary kompetencji. Kancelaria litewska odpowiadała za relacje z Moskwą, czasem Krymem. Korona zaś zajmowała się pozostałymi kierunkami. 
W ramach kancelarii wypracowywano koncepcje instrukcji poselskich, treści umów i traktatów, a także odpowiedzi na obce poselstwa. Były one również odpowiedzialne za wyposażenie emisariuszy króla i Rzeczypospolitej w konieczne dokumenty, czyli instrukcje poselskie, listy uwierzytelniające i w przypadku dłuższych podróży listy potwierdzające fakt odbywania przez niego legacji wraz z prośbą o udzielenie mu ewentualnej pomocy na obcych dworach'.

\section{Wykaz poselstw}

Zaprezentowany w tabeli 1 wykaz poselstw obejmuje zgodnie z tytułem lata 15691589. Zawarte w nim zostały oficjalne misje dyplomatyczne, realizowane z inicjatywy monarchy lub sejmu Rzeczypospolitej. Świadomie nie uwzględniłem nieformalnych aktywności wysłanników czy agentów królewskich, gdyż te, ze względu na swój charakter, zasługują na odrębne studia. Określając czas realizowania poselstwa, zostały wskazane daty roczne oraz miesięczne, bez uwzględnienia dat dziennych. Powodem przyjęcia takiej prezentacji jest niemożność ustalenie w wielu przypadkach dokładnych dat rozpoczęcia i zakończenia legacji. O ile początkową cezurę można utożsamiać z przekazaniem posłowi instrukcji oraz listów uwierzytelniających, to moment zakończenia misji jest często nieuchwytny. Wynika to z praktykowanych w dobie nowożytnej ustnych relacji, jakie posłowie zdawali przed monarchą, częstokroć podczas prywatnych audiencji. Takie finalizowanie legacji nie skutkowało wytworzeniem dokumentacji, która mogłaby dziś stanowić interesujące źródło (Przyboś, Żelewski 1959: 39-44). Stąd też, wskazując czas realizowanych misji dyplomatycznych, starałem się uchwycić wyrażony w miesiącach okres między rozpoczęciem poselstwa a powrotem do kraju².

Wskazanie postaci posłów realizujących misje dyplomatyczne w sporządzonym wykazie ma dwojaką przyczynę. Z jednej strony pozwala łatwo zobrazować fakt wysyłania kilku misji w podobnym czasie i tym samym kierunku oraz wskazać na fakt "wyspecjalizowania się" poszczególnych posłów w prowadzeniu misji dyplomatycznych na konkretnych dworach. Nie zawsze jednak dotychczasowe badania pozwoliły ustalić skład personalny wszystkich poselstw, w takim przypadku ograniczę się do odnotowania samego faktu odbycia legacji i określenia jej kierunku.

\footnotetext{
${ }^{1}$ Przykładowym zestawem dokumentów, w które wyposażony był poseł pełniący misję zagraniczną, był ten przekazany Janowi Konarskiemu, legatowi do cesarza Maksymiliana II. Dnia 26 kwietnia 1570 r. roku otrzymał on instrukcje poselskie, następnie pełnomocnictwa królewskie, listy uwierzytelniające oraz listy żelazne. O organizowanej legacji zostali poinformowani także przebywający w Polsce posłowie państw, przez które będzie przejeżdżał orszak biskupa Konarskiego, celem udzielenia mu ewentualnej pomocy (Archiwum Główne Akt Dawnych w Warszawie, Metryka Koronna, Księga Poselstw nr 19, k. 218-223.)

${ }^{2}$ W wielu przypadkach powrót posła do kraju nie był bezpośrednio związany z zakończeniem w tym czasie misji poselskiej. Przykładem tego stanu rzeczy był choćby posłujący na Krym poseł Andrzej Taranowski, któremu z powodu trwających sporów polsko-tatarskich uniemożliwiano powrót do kraju przez blisko rok (Wójcik 1982: 15-16).
} 
Jak już wspomniano, celem niniejszego artykułu nie jest rzecz jasna przedstawienie pełnego obrazu funkcjonowania polskiej dyplomacji w latach 1569-1589, ale wskazanie jej obszarów i intensywności działania na określonych kierunkach. W związku z tym wykorzystany materiał źródłowy nie jest w żadnym wypadku wynikiem szczegółowej, wyczerpującej kwerendy biblioteczno-archiwalnej. Podstawą źródłową, pozwalającą na opracowanie "wykazu poselstw”, są księgi Wpisów (Archiwum Główne Akt Dawnych w Warszawie, Metryka Koronna, Księgi Wpisów Libri Inscriptionum, nr 106135) i Księgi Poselstw Metryki Koronnej (Archiwum Główne Akt Dawnych w Warszawie, Metryka Koronna, Księgi Poselstw Libri Legationum, nr 19, 20, 21, 25, 26, 27, 28, 41) oraz ich sumariusze (Krawczuk 2004; Woźniakowa 1999; Pawiński 1882; Sokółi in. 2001; Wierzbowski 1919). Istotnym uzupełnieniem niekiedy nieprecyzyjnych odpisów znajdujących się we wspomnianych materiałach są wydawnictwa źródłowe, zawierające głównie korespondencję dyplomatyczną oraz odpisy instrukcji czy relacji poselskich (Abrahamowicz 1959; Barycz 1939; Janicki 1872; Kalinowska 1992; Sobieski 1904).

W celu identyfikacji postaci legatów Rzeczypospolitej i określenia ich funkcji w momencie sprawowania poselstwa wykorzystane zostały w głównej mierze artykuły zawarte w Polskim słowniku biograficznym. Interesującymi, choć wymagającymi ciągłej weryfikacji, są wydawane przez Ministerstwo Spraw Zagranicznych II Rzeczypospolitej Roczniki Służby Zagranicznej Rzeczypospolitej Polskiej z lat 1933-1938 i zawarte tam wykazy historyczne wykazy polskich przedstawicieli w poszczególnych państwach. Uzupełniając te materiały o wybraną literaturę przedmiotu, udało się, moim zdaniem, przedstawić pewien ogólny obraz kierunków i aktywności dyplomacji Rzeczypospolitej w latach 1569-1589.

Tabela 1. Wykaz poselstw i posłów rzeczypospolitej z lat 1569-1589

\begin{tabular}{|c|c|c|c|}
\hline Lp. & $\begin{array}{c}\text { Przybliżony czas } \\
\text { realizowania } \\
\text { poselstwa }\end{array}$ & Kierunek/odbiorca poselstwa & Reprezentacja poselska \\
\hline 1 & 1569 (luty) & $\begin{array}{l}\text { Basza Budy przedstawiciel sułtana } \\
\text { Selima II na Węgrzech }\end{array}$ & Jan Maciejowski ${ }^{3}$ \\
\hline 2 & $\begin{array}{l}1568 \text { (październik) - } \\
1569 \text { (maj) }\end{array}$ & $\begin{array}{l}\text { Fryderyk II król Danii (Kopenhaga), } \\
\text { Lubeka }\end{array}$ & $\begin{array}{l}\text { Piotr Kłoczewski }{ }^{4} \text {, Jan Dymitr } \\
\text { Solikowski }{ }^{5}\end{array}$ \\
\hline
\end{tabular}

\footnotetext{
3 Jan Maciejowski h. Ciołek (zm. 1587), protestant, przedstawiciel kalwinizmu, podkomorzy sandomierski, w latach 1574-1579 awansował na senatorskie krzesło kasztelana czechowskiego, następnie w roku 1581 został mianowany kasztelanem zawichojskim. W jego posiadaniu było także starostwo łęczyckie, które zachował do dnia śmierci (Opaliński, Żerek-Kleszcz 1993: 195).

${ }^{4}$ Piotr Kłoczowski h. Rawicz, od 1577 r. kasztelan zawichojski, starosta małogoski, zm. 1580 (Żelewski 1967: 52-54).

5 Jan Dymitr Solikowski h. Bończa (1539-1603), od 1564 sekretarz w kancelarii królewskiej w czasach kanclerstwa Walentego Dembińskiego, w latach 1576-1582 scholastyk łęczycki i kustosz sandomierski, od 1583 arcybiskup Iwowski (Kotarski, Kumor 2000-2001: 282-289).
} 


\begin{tabular}{|c|c|c|c|}
\hline Lp. & $\begin{array}{c}\text { Przybliżony czas } \\
\text { realizowania } \\
\text { poselstwa }\end{array}$ & Kierunek/odbiorca poselstwa & Reprezentacja poselska \\
\hline 3 & $\begin{array}{l}1569 \text { (marzec- } \\
\text { czerwiec) }\end{array}$ & Fryderyk II król Danii (Kopenhaga) & Andrzej Taranowski ${ }^{6}$ \\
\hline 4 & 1569 (czerwiec) & Aleksander II wojewoda wołoski & Jan Sienieński ${ }^{7}$ \\
\hline 5 & 1569 (lipiec) & Jan III król Szwecji (Sztokholm) & Erazm Dembiński ${ }^{8}$ Jost Clodt ${ }^{9}$ \\
\hline 6 & $\begin{array}{l}1569 \text { (sierpień) - } \\
1570 \text { (styczeń) }\end{array}$ & $\begin{array}{l}\text { Jan III król Szwecji, Katarzyna } \\
\text { Jagiellonka królowa Szwecji }\end{array}$ & Erazm Dembiński, Jost Clodt \\
\hline 7 & $\begin{array}{l}1569 \text { (październik- } \\
\text { listopad) }\end{array}$ & $\begin{array}{l}\text { Fryderyk II król Danii (Kopenhaga), } \\
\text { Szczecin }\end{array}$ & $\begin{array}{l}\text { Jan Dymitr Solikowski, Marcin } \\
\text { Kromer }^{10}\end{array}$ \\
\hline 8 & 1569 (październik) & $\begin{array}{l}\text { Juliusz książę Brunszwiku i Lune- } \\
\text { burga, Zofia Jagiellonka księżna } \\
\text { brunszwicka, Joachim elektor } \\
\text { brandenburski, August książę } \\
\text { elektor Saksonii }\end{array}$ & Stanisław Sędziwuj Czarnkowski" \\
\hline 9 & $\begin{array}{l}1569 \text { (listopad) - } \\
1570 \text { (luty) }\end{array}$ & Meklemburgia (Roztok) & $\begin{array}{l}\text { Piotr Kłoczewski }{ }^{12} \text {, Jan Dymitr Soli- } \\
\text { kowski, Marcin Kromer }\end{array}$ \\
\hline 10 & 1569 (listopad) & $\begin{array}{l}\text { Jan II Zygmunt Zapolya król elekt } \\
\text { Węgier }\end{array}$ & Jakub Woroniecki \\
\hline
\end{tabular}

${ }^{6}$ Andrzej Taranowski, wywodzący się z niezamożnej ruskiej szlachty z Taranowic, sekretarz królewski. Być może podczaszy halicki w latach 1570-1579, choć nie występował z tym tytułem w znanych mi źródłach (Przyboś 1987: 52, nr 189; AGAD, MK 101, k. 160; Turowski 1858: 427-428).

7 Jan Sienieński h. Dębno (zm. ok. 1599 r.), w roku 1568 król powierzył mu urząd kasztelana żarnowskiego. Wierny stronnictwu antyhabsburskiemu promował kandydaturę Stefana Batorego, za co w roku 1584 uzyskał kasztelanię Iwowską (Kowalska 1996: 185-188).

${ }^{8}$ Erazm Dembiński, sekretarz królewski, chorąży wielki koronny (Chłapowski i inni 1992: 27).

9 Just Clodt vel Justus Claudius, wywodził się z inflanckiej rodziny zamieszkałej w Rewalu. Swoją karierę poza rodzinnym miastem rozpoczął na dworze Gottharda Kettlera, gdzie sprawował funkcję kanclerza księstwa kurlandzkiego. Mianowany w 1566 r. sędzią ziemskim inflanckim, pełnił ten urząd do śmierci w 1572 r. W kancelarii królewskiej Zygmunta Augusta jako sekretarz zajmował się dobrze znanymi sobie sprawami inflanckimi, za co został wynagrodzony starostwem w Jurborku, które otrzymał na własność w 1562 roku (Mikulski, Rachuba 1994: 38, 202).

${ }^{10}$ Marcin Kromer (1512-1589) po odbyciu studiów zagranicznych, zakończonych uzyskaniem tytułu doktora obojga praw, rozpoczął pracę w kancelarii biskupa krakowskiego Piotra Gamrata. Dzięki swym protektorom w 1542 uzyskał probostwo bieckie, a następnie wszedł do kapituły katedry krakowskiej. Kromer szybko zyskiwał kolejne beneficja kościelne, m.in. kustodię w Wiślicy i Sandomierzu czy kanonię w Kielcach. W roku 1569 otrzymał ważną godność koadiutora biskupstwa warmińskiego, by dekadę później objąć to biskupstwo (Barycz 1970: 319-325).

${ }^{11}$ Stanisław Sędziwój Czarnkowski h. Nałęcz (1526-1602) od 1567 r. komandor joannitów poznańskich, następnie referendarz koronny, od 1569 starosta drahimski, inowłodzki i płocki (Lepszy 1938: 221-225).

${ }^{12}$ Piotr Kłoczewski (Kłoczowski) h. Rawicz (ok. 1541-1580), od roku 1565 na dworze króla Zygmunta Augusta, jako jeden z sekretarz królewskich, w latach 1567-1577 pełnił szereg misji dyplomatycznych, ze szczególnym uwzględnieniem kierunku północnego, w roku 1577 mianowany kasztelanem zawichojskim, trzy lata później król powierzył mu także dożywotnio starostwo małogoskie (Żelewski 1967: 52-53). 


\begin{tabular}{|c|c|c|c|}
\hline Lp. & $\begin{array}{l}\text { Przybliżony czas } \\
\text { realizowania } \\
\text { poselstwa }\end{array}$ & Kierunek/odbiorca poselstwa & Reprezentacja poselska \\
\hline 11 & $\begin{array}{l}1569 \text { (listopad) - } \\
1570 \text { (luty) }\end{array}$ & Iwan IV (Moskwa) & Jan Krotoski ${ }^{13}$, Mikołaj Talwosz \\
\hline 12 & $\begin{array}{l}1570 \text { (styczeń- } \\
\text { marzec) }\end{array}$ & $\begin{array}{l}\text { Jan III król Szwecji, Katarzyna } \\
\text { Jagiellonka królowa Szwecji }\end{array}$ & Jost Clodt \\
\hline 13 & 1570 (marzec) & Adolf I książę Holsztynu-Gottorp & $?$ \\
\hline 14 & 1570 (styczeń-maj) & $\begin{array}{l}\text { Fryderyk II król Danii, Jan III Waza } \\
\text { król Szwecji }\end{array}$ & $\begin{array}{l}\text { Erazm Dembiński, Just Clodt, Jerzy } \\
\text { von Eden }\end{array}$ \\
\hline 15 & 1570 (styczeń-luty) & Gotard Kettler książę Kurlandii & Jost Clodt \\
\hline 16 & $\begin{array}{l}1570 \text { (kwiecień- } \\
\text { sierpień) }\end{array}$ & $\begin{array}{l}\text { Cesarz Maksymilian II Habsburg } \\
\text { (sejm Rzeszy w Spirze) }\end{array}$ & Adam Konarski $i^{14}$, Łukasz Podoski ${ }^{15}$ \\
\hline 17 & $\begin{array}{l}1570 \text { (kwiecień- } \\
\text { czerwiec) }\end{array}$ & $\begin{array}{l}\text { Albrecht Fryderyk Hohenzollern, } \\
\text { książę pruski }\end{array}$ & Jan Dymitr Solikowski \\
\hline 18 & 1570 (lipiec) & Ryga & $\begin{array}{l}\text { Jerzy Pietkiewicz }{ }^{16} \text {, Michał Dzia- } \\
\text { łyński', Jakum Meknim, Szymon } \\
\text { Krzywański }\end{array}$ \\
\hline 19 & 1570(lipiec) & Gotard Kettler książę Kurlandii & Szymon Krzywański \\
\hline 20 & 1570 (sierpień) & $\begin{array}{l}\text { Jan III Waza król Szwecji, Katarzy- } \\
\text { na Jagiellonka, królowa Szwecji } \\
\text { (Sztokholm) }\end{array}$ & Andrzej Spil \\
\hline 21 & 1571 (kwiecień) & Chan Dewelt Girej (Krym) & Jerzy Bykowski \\
\hline 22 & $\begin{array}{l}1571 \text { (kwiecień - } \\
\text { październik) }\end{array}$ & Cesarz Maksymilian II Habsburg & Adam Konarski \\
\hline
\end{tabular}

${ }_{13}$ Jan Krotoski, h. Leszczyc (1552-1583), od 1576 sekretarz królewski, mianowany w październiku 1582 kasztelanem inowrocławskim, piastował urząd starosty rogozińskiego (Żelewski 1970: 345-347).

${ }^{14}$ Adam Konarski (1526-1574), w latach 1548-1552 dworzanin i sekretarz królewski, pełnił przez krótki czas urząd podkomorzego poznańskiego. Przechodząc w stan duchowny, wystarał się o prepozyturę poznańską, a następnie przy znacznej przychylności i zaangażowaniu króla Zygmunta II Augusta, w roku 1562 otrzymał godność biskupa poznańskiego, które objął w dwa lata później (Żelewski 1967-1968: 447-449).

${ }^{15}$ Łukasz Podoski h. Junosza (1526-1584). Wywodzący się z ziemi ciechanowskiej szlachcic prawdopodobnie wzorem swojego krewnego i imiennika Łukasza Podoskiego kanonika płockiego wybrał drogę duchownego i dyplomaty. Pierwsze beneficjum kościelnym była kanonia kielecka, którą objął w roku 1551. Kolejnymi godnościami były kanonia w katedrze krakowskiej oraz prepozytura w katedrze gnieźnieńskiej (Żelewski 1983: 171-173).

${ }^{16}$ Jerzy Pietkiewicz h. Działosza (zm. 1574), w listopadzie 1563 występował jako kanonik żmudzki, w 1567 r. otrzymał godność biskupa żmudzkiego (Lulewicz 1981: 154-155).

${ }^{17}$ Michał Działyński (zm. 1576), w roku 1551 mianowany został na urząd podkomorzego pomorskiego, by w rok później sięgnąć po podkomorstwo chełmińskie, z którym to tytułem występował już do śmierci (Bodniak 1948: 90-91). 


\begin{tabular}{|c|c|c|c|}
\hline Lp. & $\begin{array}{c}\text { Przybliżony czas } \\
\text { realizowania } \\
\text { poselstwa }\end{array}$ & Kierunek/odbiorca poselstwa & Reprezentacja poselska \\
\hline 23 & $\begin{array}{l}1571 \text { (kwiecień- } \\
\text { sierpień) }\end{array}$ & Siedmiogród & $\begin{array}{l}\text { Mikołaj Mielecki }{ }^{18}, \text { Wawrzyniec } \\
\text { Goślicki }^{19}\end{array}$ \\
\hline 24 & 1571 (lipiec) & Iwan IV car Rosji (Nowogród) & Michał Haraburda ${ }^{20}$ \\
\hline 25 & $\begin{array}{l}1572 \text { (styczeń- } \\
\text { marzec) }\end{array}$ & $\begin{array}{l}\text { Zofia Jagiellonka księżna Brunszwi- } \\
\text { ku (Schöningen) }\end{array}$ & Wawrzyniec Goślicki \\
\hline 26 & 1572 (luty-kwiecień) & Selim II sułtan turecki (Stambuł) & Andrzej Taranowski \\
\hline 27 & $\begin{array}{l}1572 \text { (grudzień) - } \\
1573 \text { (kwiecień) }\end{array}$ & Iwan IV (Nowogród Wielki) & Michał Haraburda \\
\hline \multicolumn{4}{|c|}{7 lipca 1572 - umiera Zygmunt II August } \\
\hline 28 & $\begin{array}{l}1573 \text { (czerwiec- } \\
\text { wrzesień) }\end{array}$ & Henryk Walezy (Paryż) & 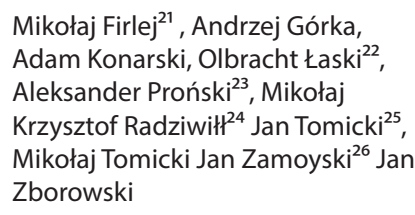 \\
\hline
\end{tabular}

\footnotetext{
${ }^{18}$ Mikołaj Mielecki h. Gryf (zm. 1585), dworzanin królewski od 1548 r. Swoją karierę rozpoczynał od objęcia starostwa chmielnickiego w toku 1557, które zamienił dwa lata później na starostwo grodeckie. Mianowany w 1567 kasztelanem wojnickim, awansował w 1569 na urząd wojewody podolskiego (Kowalska 1975: 759-65).

${ }^{19}$ Wawrzyniec Goślicki h. Grzymała (ok. 1530-1607), duchowny. Po odbyciu włoskich studiów i powrocie do kraju rozpoczął pracę w kancelarii królewskiej Zygmunta Augusta. W roku 1572 otrzymał pierwsze prebendy kościelne, tj. probostwo płockie i kanonię krakowską. Sekretarz króla Stefana Batorego, w imieniu którego realizował szereg misji do książąt Rzeszy. W latach 80. awansował kolejno na dziekana kieleckiego i kantora płockiego. Dzięki poparciu króla otrzymał w 1586 r. biskupstwo kamienieckie i tytuł opata w Mogile (Maniewska 1960: 379-383).

${ }^{20}$ Michał Haraburda h. Abdank (zm. 1586), litewski dworzanin Zygmunta Augusta, sekretarz w kancelarii litewskiej, otrzymał w 1579 roku starostwo świsłockie, w 1584 roku sięgnął po senatorskie krzesło kasztelana mińskiego (Lepszy 1960-1961: 288-290).

${ }^{21}$ Mikołaj Firlej h. Lewart (zm. 1588), od 1577 kasztelan rawski, za wierną służbę królowi Stefanowi Batoremu otrzymał w 1586 starostwo kamionackie. Po śmierci króla swój majątek i autorytet postawił na kandydaturę Zygmunta Wazy, co przyszły władca wynagrodził mu nadaniem godności wojewody lubelskiego (Lepszy 1948-1958: 10-12).

${ }^{22}$ Olbracht Łaski h. Korab (1535-1606), syn sławnego dyplomaty, wojewody sieradzkiego Hieronima Łaskiego, także wojewoda sieradzki. Związany z domem Habsburgów prowadził na poły prywatną, na poły proniemiecką politykę, wielokrotnie sprzeczną z bieżącymi interesami Polski i Litwy. W wyniku powiązań rodzinnych oraz znacznego majątku, Łaskiemu udało się otrzymać urząd wojewody sieradzkiego, który sprawowali także jego stryj, ojciec i dziad (Żelewski 1973: 246-250).

${ }^{23}$ Aleksander Proński h. Św. Jerzy (ok. 1550-1596), w latach 1576-1587 stolnik, a następnie chorąży litewski i starosta łucki, od 1587 kasztelan trocki (Żelewski 1985: 507-509).

${ }^{24}$ Mikołaj Krzysztof Radziwiłł h. Trąby (1549-1616), od roku 1569 marszałek nadworny litewski, a następnie marszałek wielki litewski. W latach 1586-1590 był kolejno kasztelanem trockim, wojewodą trockim, a wreszcie wojewodą wileńskim (Lulewicz 1987: 349-361).

${ }^{25}$ Jan Tomicki, kasztelan Rogoziński, awansował w roku 1564 na kasztelanię gnieźnieńską.

${ }^{26}$ Jan Zamoyski h. Jelita (1542-1605) w czasie sprawowania legacji do Paryża sekretarz królewski i starosta knyszyński, późniejszy kanclerz i hetman wielki koronny.
} 


\begin{tabular}{|c|c|c|c|}
\hline Lp. & $\begin{array}{l}\text { Przybliżony czas } \\
\text { realizowania } \\
\text { poselstwa }\end{array}$ & Kierunek/odbiorca poselstwa & Reprezentacja poselska \\
\hline \multicolumn{4}{|c|}{21 lutego 1574 - koronacja Henryka Walezego } \\
\hline 29 & $\begin{array}{l}1574 \text { (listopad) - } \\
1575 \text { (marzec) }\end{array}$ & Henryk Walezy (Lyon-Awinion) & $\begin{array}{l}\text { Jan Tomasz Drohojowski }{ }^{27} \text {, Hiero- } \\
\text { nim Rozdrażewski }\end{array}$ \\
\hline 30 & 1575 (luty-marzec) & Murad III sułtan turecki (Stambuł) & Andrzej Taranowski \\
\hline 31 & 1576 (styczeń) & Maksymilian II Habsburg cesarz & Olbracht Łaski \\
\hline \multicolumn{4}{|c|}{ 1-2 maja 1576 - sejm koronacyjny Stefana Batorego } \\
\hline 32 & 1576 (maj-wrzesień) & Murad III sułtan turecki (Stambuł) & Krzysztof Dzierżek ${ }^{28}$ \\
\hline 33 & 1576 (maj-grudzień) & $\begin{array}{l}\text { Ratyzbona (na sejm Rzeszy Nie- } \\
\text { mieckiej), dwór cesarza Maksymi- } \\
\text { liana II Habsburga }\end{array}$ & Jan Dymitr Solikowski, Jan Krotoski \\
\hline 34 & $\begin{array}{l}1576 \text { (wrzesień- } \\
\text { listopad) }\end{array}$ & Papież Grzegorz XIII (Rzym) & Jan Grzymała Zamoyski ${ }^{29}$ \\
\hline 35 & 1576 (jesień) & Iwan IV (Moskwa) & $\begin{array}{l}\text { Grzegorz Grudziński, Lech Buko- } \\
\text { wiecki }\end{array}$ \\
\hline 36 & 1576 (jesień) & Jan III Waza (Sztokholm) & Jan Szczęsny Herburt ${ }^{30}$ \\
\hline 37 & $\begin{array}{l}1576 \text { (wrzesień- } \\
\text { grudzień) }\end{array}$ & Jan III Waza (Sztokholm) & Wawrzyniec Goślicki \\
\hline 38 & $\begin{array}{l}1577 \text { (styczeń) } \\
-1578 \text { (sierpień) }\end{array}$ & Dewlet Gerej chan tatarski (Krym) & Andrzej Taranowski \\
\hline 39 & $\begin{array}{l}1577 \text { (styczeń- } \\
\text { marzec) }\end{array}$ & Murad III sułtan turecki (Stambuł) & Krzysztof Dzierżek \\
\hline 40 & 1577 (marzec) & $\begin{array}{l}\text { Jan Fryderyk książę pomorski } \\
\text { (Szczecin) }\end{array}$ & Prokop Broniowski \\
\hline
\end{tabular}

\footnotetext{
${ }^{27}$ Jan Tomasz Drohojowski h. Korczak (ok. 1535-1605), od 1578 starosta przemyski, w maju 1589 mianowany referendarzem koronnym (Lepszy 1939-1946: 382-384).

${ }^{28}$ Krzysztof Dzierżek, wywodzący się ze średniozamożnej szlachty h. Nieczuja, wsławił się jako jeden z najważniejszych tłumaczy języków wschodnich. Biorąc udział w licznych legacjach, sam stał się wieloletnim agentem Rzeczypospolitej w Turcji oraz posłem króla Stefana Batorego do Konstantynopola i Moskwy. Od roku 1604 piastował także urząd chorążego trockiego (Baranowski, 1948: 160-161). ${ }^{29}$ Jan Zamoyski h. Grzymała (zm. 1614), cysters, dworzanin i sekretarz króla Stefana Batorego, w latach 1595-1604 biskup sufragan płocki, od 1604 arcybiskup Iwowski (Kadzik 2016: 197).

${ }^{30}$ Jan Herburt (ok 1525-1577), pochodzący z zamożnej szlachty ruskiej, rozpoczął swoją karierę w roku 1553, przejmując po swym bracie urząd podkomorzego przemyskiego. Jako sekretarz królewski otrzymał od monarchy skomplikowane zadanie zebrania i przetłumaczenia na język polski obowiązujących w Królestwie praw. Być może to właśnie za zasługi na gruncie prawnym otrzymał on urząd kasztelana sanockiego, z którym występował w 1568 roku, a dwa lata później przekazano mu starostwo przemyskie (Żelewski 1960: 440-442).
} 


\begin{tabular}{|c|c|c|c|}
\hline Lp. & $\begin{array}{c}\text { Przybliżony czas } \\
\text { realizowania } \\
\text { poselstwa }\end{array}$ & Kierunek/odbiorca poselstwa & Reprezentacja poselska \\
\hline 41 & 1577 (maj-czerwiec) & Papież Grzegorz XIII (Rzym) & $\begin{array}{l}\text { Wojciech Borzykowski } \\
\text { Prokop Broniowski }\end{array}$ \\
\hline 42 & 1577 (maj) & Jan Fryderyk książę szczeciński & $?$ \\
\hline 43 & 1577 (maj-czerwiec) & $\begin{array}{l}\text { Jerzy Fryderyk Hohenzollern, } \\
\text { margrabia Ansbach }\end{array}$ & Wawrzyniec Goślicki \\
\hline 44 & 1577 (maj) & Piotr V wojewoda mołdawski & Jan Sienieński \\
\hline 45 & 1577 (maj-lipiec) & Papież Grzegorz XIII (Rzym) & Jan Grzymała Zamoyski \\
\hline 46 & $\begin{array}{l}1577 \text { (czerwiec- } \\
\text { lipiec) }\end{array}$ & $\begin{array}{l}\text { Jan Fryderyk ks. Pomorski (Szcze- } \\
\text { cin) }\end{array}$ & Piotr Kłoczewski \\
\hline 47 & 1577 (lipiec) & $\begin{array}{l}\text { Albrecht Fryderyk Hohenzollern } \\
\text { książę Prus }\end{array}$ & Jan Policki \\
\hline 48 & 1577 (lipiec) & $\begin{array}{l}\text { Książęta pomorscy, Jan Fryderyk } \\
\text { szczeciński (Szczecin) }\end{array}$ & Jan Bużeński \\
\hline 49 & 1577 (maj-wrzesień) & Murad III sułtan turecki (Stambuł) & Jan Sienieński ${ }^{32}$ \\
\hline 50 & 1577 (wrzesień) & Albrecht Fryderyk książę Prus & Tomasz Drohojowski \\
\hline 51 & 1577 (wrzesień) & $\begin{array}{l}\text { Patrycjat ryski, Gotard Kettler } \\
\text { książę Kurlandii }\end{array}$ & Jan Taube \\
\hline 52 & $\begin{array}{l}1577 \text { (październik- } \\
\text { listopad) }\end{array}$ & $\begin{array}{l}\text { Piotr wojewoda mołdawski, Tata- } \\
\text { rzy perekopscy }\end{array}$ & $\begin{array}{l}\text { Mikołaj Płatowski, Andrzej Tara- } \\
\text { nowski }\end{array}$ \\
\hline 53 & $\begin{array}{l}1577 \text { (listopad/gru- } \\
\text { dzień) }\end{array}$ & Murad III sułtan turecki (Stambuł) & Jan Sienieński \\
\hline 54 & $\begin{array}{l}1577 \text { (listopad/gru- } \\
\text { dzień) }\end{array}$ & $\begin{array}{l}\text { Papież Grzegorz XIII (Rzym), Seba- } \\
\text { stian Venier doża wenecki, Alfons } \\
\text { d'Este książę Ferrary, Wilhelm I, } \\
\text { książę Mantui, Franciszek I książę } \\
\text { Florencji }\end{array}$ & Paweł Uchański \\
\hline 55 & $\begin{array}{l}1577 \text { (grudzień) - } \\
\text { marzec } 1578\end{array}$ & $\begin{array}{l}\text { Jan IV wojewoda mołdawski, } \\
\text { Murad III sułtan turecki }\end{array}$ & Marek Sobieski ${ }^{33}$ \\
\hline
\end{tabular}

${ }^{31}$ Prokop Broniewski h. Leliwa, podkomorzy poznański oraz chorąży kaliski (Chodynicki 1936: 464-465).

32 Jan Sienieński h. Dębno (ok. 1532-1580), wywodząc się z zamożnej ruskiej rodzin, swoją działalność polityczną rozpoczął od poselstw sejmikowych, za co uhonorowano go w 1567 r. urzędem stolnika sanockiego. Trzy lata później występował już jako podkomorzy sanocki, a od czerwca 1576 jako kasztelan halicki (Kaniewska 1996: 188-189).

${ }^{33}$ Marek Sobieski h. Janina (ok. 1549-1605), stronnik kanclerza Zamoyskiego i króla Stefana Batorego, brał udział w kampaniach wojennych przeciwko Gdańskowi i Moskwie, od sierpnia 1580 chorąży nadworny (Gmiterek 2000: 502-504). 


\begin{tabular}{|c|c|c|c|}
\hline Lp. & $\begin{array}{c}\text { Przybliżony czas } \\
\text { realizowania } \\
\text { poselstwa }\end{array}$ & Kierunek/odbiorca poselstwa & Reprezentacja poselska \\
\hline 56 & 1578 (styczeń) & $\begin{array}{l}\text { Jan Jerzy Hohenzollern elektor } \\
\text { brandenburski }\end{array}$ & Marcin Leśniowolski ${ }^{34}$ \\
\hline 57 & $\begin{array}{l}1577 \text { (grudzień) } \\
-1578 \text { (styczeń) }\end{array}$ & $\begin{array}{l}\text { Stany Pruskie, Jerzy Fryderyk } \\
\text { (Królewiec) }\end{array}$ & $\begin{array}{l}\text { Piotr Potulicki }{ }^{35} \text { Andrzej Firlej, Jan } \\
\text { Dymitr Solikowski }\end{array}$ \\
\hline 58 & $\begin{array}{l}1578 \text { (styczeń- } \\
\text { marzec) }\end{array}$ & Iwan IV (Moskwa) & $\begin{array}{l}\text { Stanisław Kryski }{ }^{36} \text { Mikołaj Sapieha, } \\
\text { Teodor Tyszkiewicz }\end{array}$ \\
\hline 59 & $\begin{array}{l}1578 \text { (luty) }-1579 \\
\text { (maj) }\end{array}$ & Papież Grzegorz XIII (Rzym) & Paweł Zajączkowski ${ }^{37}$ \\
\hline 60 & $\begin{array}{l}1578 \text { (kwiecień- } \\
\text { sierpień) }\end{array}$ & $\begin{array}{l}\text { Mahmed Gerej chan perekopski } \\
\text { (Krym) }\end{array}$ & Marcin Broniewski \\
\hline 61 & $\begin{array}{l}1578 \text { (czerwiec- } \\
\text { wrzesień) }\end{array}$ & Ryga, ks. Kettler (Kurlandia) & Jan Tomasz Drohojowski \\
\hline 62 & $\begin{array}{l}1578 \text { (lipiec- } \\
\text { wrzesień) }\end{array}$ & Murad III sułtan turecki (Stambuł) & Andrzej Łobzowiecki \\
\hline 63 & 1578 (sierpień) & Iwan IV (Moskwa) & Piotr Haraburda \\
\hline 64 & 1578 (wrzesień) & Murad III sułtan turecki (Stambuł) & Adam Kłoczowski \\
\hline 65 & $\begin{array}{l}1578 \text { (wrzesień- } \\
\text { grudzień) }\end{array}$ & $\begin{array}{l}\text { Mahmed Gerej chan perekopski } \\
\text { (Krym) }\end{array}$ & Marcin Broniewski \\
\hline 66 & $\begin{array}{l}1578 \text { (grudzień) - } \\
1579 \text { (maj) }\end{array}$ & Cesarz Rudolf II Habsburg (Praga) & Łukasz Podoski \\
\hline 67 & 1579 (styczeń-lipiec) & Murad III sułtan turecki (Stambuł) & Andrzej Taranowski \\
\hline 68 & $\begin{array}{l}1578 \text { (maj) } \\
1580 \text { (maj) }\end{array}$ & Papież Grzegorz XIII (Rzym) & Paweł Uchański ${ }^{38}$ \\
\hline
\end{tabular}

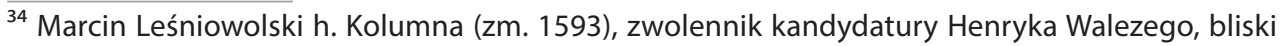
współpracownik kanclerza Jana Zamoyskiego. Mianowany w 1581 r. kasztelanem podlaskim (Kowalska 1972: 181-184).

${ }^{35}$ Piotr Potulicki h. Grzymała (zm. 1606), luteranin, w październiku 1569 wszedł do senatu jako kasztelan przemęcki. Dzięki dobrym relacjom z królem i kanclerzem Zamoyskim sukcesywnie awansował w hierarchii senatorskiej, w roku 1576 powierzono mu godność wojewody płockiego, następnie w roku 1581 województwo brzesko-kujawskie. Szczytowym momentem jego kariery było objęcie urzędu wojewody kaliskiego w sierpniu 1584 (Leitgeber 1984-1985: 252-254).

${ }^{36}$ Stanisław Kryski h. Prawdzic (ok 1536-1595), przeciwnik polityki habsburskiej, od 1563 kasztelan raciąski i starosta dobrzyński. Działając aktywnie w województwie mazowieckim, wspierał działania Stefana Batorego, za co otrzymał w roku 1576 awans na urząd wojewody mazowieckiego oraz starostwo płockie (Przyboś 1970: 486-488).

${ }^{37}$ Paweł Zajączkowski, kanonik ołomuniecki, sekretarz królewski, został wysłany jako sekretarz przyszłego poselstwa obediencyjnego, informujący papieża o dokładnej dacie przyjazdu oficjalnego poselstwa (Banaszak 1975: 125).

${ }^{38}$ Paweł Uchański h. Radwan (1548-1590), krewny arcybiskupa gnieźnieńskiego Jakuba Uchańskiego, w kwietniu 1575 mianowany kasztelanem bełskim, po ucieczce Henryka Walezego utracił ten urząd, od stycznia 1588 wojewoda bełski i starosta drohobycki (Gmiterek, Szczygieł 1992: 71).
} 


\begin{tabular}{|c|c|c|c|}
\hline Lp. & $\begin{array}{l}\text { Przybliżony czas } \\
\text { realizowania } \\
\text { poselstwa }\end{array}$ & Kierunek/odbiorca poselstwa & Reprezentacja poselska \\
\hline 69 & 1580 & Murad III sułtan turecki (Stambuł) & Krzysztof Dzierżek \\
\hline 70 & $\begin{array}{l}1580 \text { (czerwiec- } \\
\text { październik) }\end{array}$ & Cesarz Rudolf II Habsburg (Praga) & Łukasz Podoski \\
\hline 71 & 1580 (sierpień) & Wieliż & $\begin{array}{l}\text { Jan Tomasz Drohojowski, Piotr } \\
\text { Kloczowski }\end{array}$ \\
\hline 72 & 1581 (luty-maj) & Ryga & $\begin{array}{l}\text { Jan Dymitr Solikowski, Wacław } \\
\text { Agryppa }\end{array}$ \\
\hline 73 & $\begin{array}{l}1581 \text { (październik) - } \\
1582 \text { (luty) }\end{array}$ & Murad III sułtan turecki (Stambuł) & Jan Tomasz Drohojowski \\
\hline 74 & $\begin{array}{l}1581 \text { (grudzień) - } \\
1582 \text { (styczeń) }\end{array}$ & $\begin{array}{l}\text { Jam Zapolski (negocjacje pokojo- } \\
\text { we z Rosją) }\end{array}$ & $\begin{array}{l}\text { Janusz Zbaraski, Albrecht Radziwiłł, } \\
\text { Michał Haraburda }\end{array}$ \\
\hline 75 & 1582 (marzec-maj) & Jan III król Szwecji (Sztokholm) & Dominik Alamanni ${ }^{39}$ \\
\hline 76 & $\begin{array}{l}1582 \text { (marzec- } \\
\text { sierpień) }\end{array}$ & Murad III sułtan turecki (Stambuł) & Hieronim Filipowski ${ }^{40}$ \\
\hline 77 & $\begin{array}{l}1582 \text { (lipiec- } \\
\text { sierpień) }\end{array}$ & $\begin{array}{l}\text { Cesarz Rudolf II Habsburg, elekto- } \\
\text { rzy Brandenburgii, Kolonii, Mogun- } \\
\text { cji, Palatynatu, Saksonii, Trewiru }\end{array}$ & Hieronim Rozdrażewski \\
\hline 78 & $\begin{array}{l}1582 \text { (marzec- } \\
\text { sierpień) }\end{array}$ & Iwan IV (Moskwa) & $\begin{array}{l}\text { Janusz Zbaraski, Mikołaj Tałwosz, } \\
\text { Michał Haraburda }\end{array}$ \\
\hline 79 & $\begin{array}{l}1583 \text { (kwiecień- } \\
\text { październik) }\end{array}$ & Elżbieta I (Londyn) & Olbracht Łaski \\
\hline 80 & $\begin{array}{l}1583 \text { (wrzesień- } \\
\text { październik) }\end{array}$ & Juliusz ks. Brunszwiku & Wawrzyniec Goślicki \\
\hline 81 & 1583 (grudzień) & Papież Grzegorz XIII (Rzym) & Andrzej Batory \\
\hline 82 & $\begin{array}{l}1583 \text { (listopad) - } \\
1584 \text { (kwiecień) }\end{array}$ & Murad III sułtan turecki (Stambuł) & Piotr Słostowski \\
\hline 83 & 1584 (luty-sierpień) & $\begin{array}{l}\text { Przedstawiciele angielskiej kompa- } \\
\text { nii wschodniej (Elbląg) }\end{array}$ & Piotr Potulicki \\
\hline
\end{tabular}

${ }^{39}$ Dominik Alamani, Florentczyk, w latach 1570-1578 pełnił urząd stolnika lubelskiego, zaś w latach 1577-1588 pełnił funkcję kuchmistrza nadwornego (Kłaczewski, Urban 1991: 54; Chłapowski i in. 1992: 70).

${ }^{40}$ Hieronim Filipowski h. Pobóg (zm. 1587), od lat młodzieńczych związany z siedmiogrodzkim dworem Stefana Batorego, u boku którego służył jako żołnierz i poseł. Wykorzystując rodzinne koneksje, miał istotny wkład w pozytywną dla Batorego elekcję. Wdzięczność królewska przejawiała się w kolejnych awansach Filipowskiego. Początkowo jako łożniczy królewski w 1578 roku został starostą nurskim i ostrowskim, następnie w 1582 r. ostrołęckim i stryjskim. Po zakończeniu udanej misji do Stambułu w 1583 r. mianowany został krajczym koronnym (Szczotka 1949: 495-496). 


\begin{tabular}{|c|l|l|l|}
\hline Lp. & $\begin{array}{c}\text { Przybliżony czas } \\
\text { realizowania } \\
\text { poselstwa }\end{array}$ & \multicolumn{1}{|c|}{ Kierunek/odbiorca poselstwa } & \multicolumn{1}{|c|}{ Reprezentacja poselska } \\
\hline 84 & $\begin{array}{l}1584 \text { (marzec- } \\
\text { sierpień) }\end{array}$ & Iwan IV, Fiodor Iwanowicz & Lew Sapieha ${ }^{41}$ \\
\hline 85 & 1584 (wrzesień) & Parnawa & $\begin{array}{l}\text { Andrzej Firlej, Jan Leśniowolski, } \\
\text { Krzysztof Zienowicz, Jan Piotrowski }\end{array}$ \\
\hline 86 & 1585 (maj-lipiec) & $\begin{array}{l}\text { Republika Zjednoczonych Pro- } \\
\text { wincji }\end{array}$ & Krzysztof Głoskowski \\
\hline 87 & 1585 (maj-lipiec) & $\begin{array}{l}\text { Filip II Habsburg król Hiszpanii } \\
\text { (Madryt) }\end{array}$ & Stanisław Sobocki42 \\
\hline 89 & $\begin{array}{l}1585 \text { (grudzień) }- \\
1586 \text { (maj) }\end{array}$ & $\begin{array}{l}\text { Przedstawiciele Fiodora Iwanowi- } \\
\text { cza (Grodno) }\end{array}$ & Lew Sapieha \\
\hline 90 & $\begin{array}{l}1586 \text { (maj- } \\
\text { grudzień) }\end{array}$ & Sykstus V (Rzym) & Michał Haraburda \\
\hline 91 & $\begin{array}{l}1588 \text { (marzec) }- \\
1590 \text { (wrzesień) }\end{array}$ & $\begin{array}{l}\text { Papież Sykstus V (Rzym), Signoria } \\
\text { (Wenecja) }\end{array}$ & $\begin{array}{l}\text { Jan Dymitr Solikowski, Andrzej } \\
\text { Batory }\end{array}$ \\
\hline 92 & $\begin{array}{l}1589 \text { (luty-marzec) } \\
\text { Stanisław Reszka }{ }^{43}\end{array}$ \\
\hline 93 & $\begin{array}{l}\text { Będzin, Bytom } \\
\text { lipiec) }\end{array}$ & Rudolf II Habsburg (Praga) & $\begin{array}{l}\text { Krzysztof Zienowicz, Hieronim } \\
\text { Rozdrażewski, Andrzej Opaliński, } \\
\text { Stanisław Gostomski, Janusz Ostro- } \\
\text { gski, Jan Zamoyski }\end{array}$ \\
\hline
\end{tabular}

Zawarte w powyższym zestawieniu misje dyplomatyczne, które królowie i sejm Rzeczypospolitej inicjowali w latach 1569-1589, ilustrują, w moim przekonaniu, obszar zainteresowań polskiej dyplomacji oraz jej kierunki. Na 93 wyszczególnione misje

\footnotetext{
${ }^{41}$ Lew Sapieha (1557-1633), w latach 1581-1585 starosta słonimski, brzeski i mohylewski, od roku 1585 podkanclerzy litewski, następnie wielki kanclerz litewski, wojewoda wileński i hetman wielki litewski (Przyboś, Żelewski 1959: 115-118).

${ }^{42}$ Stanisław Sobocki h. Korab (zm. 1589), pochodził z niezamożnej rodziny kaliskiej, co zapewne przyczyniło się do wybrania kariery wojskowej. Brał udział w kampaniach Stefana Batorego przeciw Moskwie, w czasie których wielokrotnie odznaczył się męstwem. Za swoją postawę był wielokrotnie wynagradzany przez króla i kanclerza Zamoyskiego. Swoją przygodę wojskową kontynuował w Niderlandach, gdzie wraz z bratankiem Batorego Baltazarem walczył po stronie hiszpańskiej (Dembiński 1999: 354-355).

${ }^{43}$ Stanisław Reszka (1544-1600), pochodził z mieszczańskiej rodziny wielkopolskiej. Krótko po odbyciu studiów związał się z dworem biskupa warmińskiego, a następnie kardynała Stanisława Hozjusza, stając się z czasem jego sekretarzem i towarzyszem licznych misji zagranicznych. Przez wiele lat bawił u boku swego protektora w Rzymie, za co został nagrodzony kanonią warmińską. Otrzymał także pewne honorowe godności w Rzymie z rąk papieża Grzegorza XIII. Opiekun i ochmistrz Andrzeja Batorego, z którym podróżował do Włoch. W roku 1585 mianowany opatem cystersów w Jędrzejowie (Kalinowska 1988: 129-133).
} 
poselskie, mające w niektórych przypadkach kilku adresatów, najwięcej, bo 15, kierowano na dwory sułtańskie Selima II, a następnie Murada III. Na podobnym poziomie intensywności utrzymywano relacje dyplomatyczne z Rosją, posyłając tam legatów 11 razy. Bezpośrednio do stolicy, na carski dwór, posłowano 9 razy, dwie misje miały charakter pertraktacji pokojowych. Silne relacje łączyły Rzeczpospolitą z państwami niemieckimi. Do książąt pomorskich, Brunszwiku, Meklemburgii, Saksonii i innych księstw Rzeszy wyprawiono łącznie 11 legacji. Dziewięciokrotnie przedstawiciele króla i Rzeczypospolitej pojawiali się na dworze cesarskim i papieskim. Jak istotną rolę w polityce odgrywały sprawy północne świadczyć może fakt wyprawienia 8 legacji na teren Inflant, 7 do Szwecji, 4 do Danii i 4 do Prus Książęcych. Stałe zagrożenie granicy południowo-wschodniej wymagało poza działaniami militarnymi także aktywności dyplomatycznej. W związku z tym pięciokrotnie organizowano legacje do tzw. księstw naddunajskich, czyli Wołoszczyzny, Siedmiogrodu i Mołdawii.

Czterokrotnie zaś dyplomaci odwiedzali Krym, pertraktując z chanem tatarskim. Niemal na marginesie pozostawały inne kierunki, jak Anglia, Holandia, czy Hiszpania, gdzie posyłano legatów zaledwie raz lub w przypadku Francji dwukrotnie. Analizując powyższe informacje, warto zwrócić uwagę na szereg zagadnień dotyczących relacji kierunków wysyłanych poselstw z wydarzeniami geopolitycznymi i ogólnymi priorytetami kolejnych władców.

\section{Kierunki aktywności polskiej dyplomacji}

\section{Polityka bałtycka. Poselstwa do Inflant i Skandynawii}

Ostatnia dekada panowania Zygmunta II Augusta cechowała się szczególną aktywnością polityczną na obszarze nadbałtyckim, tj. w Prusach, Meklemburgii, Inflantach i krajach skandynawskich. Wiązało się to bezpośrednio w wydarzeniami określanymi jako walki o dominium Maris Baltici, czyli o dominację w basenie Morza Bałtyckiego ${ }^{44}$. Podstawowym celem strony polsko-litewskiej było utrzymanie wpływów na terenie Inflant, co istotne wpływało na bezpieczeństwo Wielkiego Księstwa i rozszerzało możliwości prowadzenia handlu morskiego. Zagrożeniem dla tych planów była agresywna polityka duńska i zagrożenie Inflant ze strony Moskwy. Geograficzne usytuowanie konfliktu powodowało, że konieczne było zawiązanie sojuszu z choćby jednym krajem skandynawskim, tak aby nie doprowadzić do samotnej walki na wielu frontach. W tym celu dyplomacja polska włączyła się w trwającą wojnę duńsko-szwedzką, wspierając w staraniach o tron sztokholmski Jana III Wazę. Wyrazem tego sojuszu było małżeństwo księcia Finlandii z Katarzyną Jagiellonką, siostrą króla (Cynarski, 2004: 174-179).

W ciągu trzech ostatnich lat panowania Zygmunta II Augusta wyprawiono do Danii, Szwecji, Kurlandii 13 poselstw, w których króla i Rzeczpospolitą reprezentowało

\footnotetext{
${ }^{44}$ Problem ten ma swoją obszerną literaturę przedmiotu (m.in. Bodniak 1929; Lepszy 1946; Odyniec 1982; Piwnicki, Klein 2012; Samsonowicz 1982).
} 
7 rozpoznanych posłów. W misjach tych wyróżniali się Jan Dymitr Solikowski i Piotr Kłoczowski oraz sekretarz królewski Jost Clodt Jürgensburg. Intensywność działań dyplomatycznych wynikała z trwającego blisko dekadę konfliktu nadbałtyckiego, który nie przynosił jednoznacznych rozstrzygnięć. Skutkowało to przede wszystkim długotrwałymi blokadami w żegludze morskiej i poważnymi stratami ekonomicznymi wszystkich stron. Zakończenie kwestii inflanckiej miał przynieść zwołany do Szczecina kongres pokojowy. Podstawowym celem polskiej dyplomacji było zatwierdzenie praw do Inflant i zablokowanie portu narewskiego, z którego żeglowały konkurencyjne dla portów polskich statki handlowe, ale i stacjonować mogły okręty wojenne. Drugą kwestią było uzyskanie możliwie korzystnych warunków pokojowych dla Szwecji, która zagrożona ze strony Moskwy i Danii mogła okazać się chwiejnym sojusznikiem. Równie istotną sprawą było osłabienie współpracy Magnusa ks. Danii i Holsztynu z Iwanem IV, stanowiącym główne zagrożenie dla Inflant. Dyplomacja polska starała się działać z pozycji mediatora, nie zaś strony w konflikcie, co szybko zyskało szwedzką dezaprobatę, ale doprowadziło pośrednio do zawarcia w grudniu $1570 \mathrm{r}$. porozumień kongresowych. W ich efekcie Szwecja traciła na rzecz Danii część swych posiadłości, w tym strategicznie położony Rewel. Mimo istotnego zaangażowania sił dyplomatycznych efekt końcowy polskich starań o wpływ na politykę skandynawską był niewielki. Nie udało się doprowadzić do blokady żeglugi narewskiej i powszechnego zatwierdzenia prawa do Inflant (Bodniak 1929: 3-17).

Kontynuatorem polskich starań o dominację w Inflantach był król Stefan Batory. Już w 1576 podjął rywalizację z księciem duńskim Magnusem i sprzyjającą mu Moskwą Iwana IV, który wykorzystując zaangażowanie Rzeczypospolitej w konfliktach z Gdańskiem, wkroczył zbrojnie na teren Inflant. Chcąc przeciwdziałać zagrożeniu, polscy dyplomaci starali się uzyskać przeciwwagę dla niebezpiecznego sojuszu, szukając wsparcia u księcia kurlandzkiego Gotarda Kettlera, do którego posłował Jan Taube, a także elektora saskiego Augusta Wettyna oraz Jana III Wazy, gdzie posłano dwukrotnie Wawrzyńca Goślickiego i Jana Szczęsnego Herburta. Mimo początkowych klęsk, jakie spadły na Inflanty w postaci bezwzględnych działań wojsk moskiewskich, zakończenie konfliktu z Gdańskiem pozwoliło Batoremu organizować odsiecz. Współdziałając z Kettlerem i Janem III Wazą, wojska Rzeczypospolitej zdołały odzyskać zajęte przez Moskwę tereny, a także zabezpieczyć Inflanty przed kolejnymi uderzeniami. Sukces militarny szedł tym razem w parze z dyplomatycznym. Dzięki kontrofensywie w Inflantach Stefan Batory doprowadził do przyłączenia Kurlandii, którą w hołdzie lennym przekazał królowi książę Gotard Kettler (Topolski 2015: 212-213). Pozytywnie zakończyły się także trwające od roku 1577 rokowania polsko-ryskie, dotyczących podporządkowania tego niezwykle ważnego miasta Rzeczypospolitej. Pierwszym etapem tejże finalizacji był wydany w styczniu 1581 roku przywilej Stefana Batorego „Privilegium Stephaneum", a następnie odebranie przez polskich posłów hołdu lennego Rygi z 7 kwietnia 1581 (Ziemlewska 2008: 61-75). 


\section{Prusy i Rzesza Niemiecka}

Równie istotną sprawą, którą przez długie lata zajmowała się polska dyplomacja, była kwestia relacji Rzeczypospolitej z Prusami i Brandenburgią. Jeszcze w latach 50. XVI wieku Joachim II, elektor brandenburski, podjął starania o przyznanie praw do sukcesji w Prusach Książęcych także jego linii rodziny Hohenzollernów, w przypadku wygaśnięcia bezpośrednich potomków księcia Albrechta. Jako małżonek córki Zygmunta I Jadwigi Jagiellonki stał się powinowatym polskiego władcy, co chętnie wykorzystywał dla wzmocnienia swojej pozycji politycznej. Założone cele elektor osiągnął w roku 1563, kiedy to Zygmunt II August, jako suweren Prus Książęcych, rozciągnął prawo do sukcesji na linię brandenburską, czyli potomków Joachima II, Jana Jerzego i Zygmunta Hohenzollernów. Królewskie postanowienie nie weszło jednak w życie w momencie jego wydania. O prawa do lenna pruskiego upomniał się bowiem Jan Albrecht I, książę Meklemburgii, szwagier Joachima II. Żyjący w dobrych relacjach z księciem pruskim Albrechtem Hohenzollernem, ciepiącym od 1563 roku na liczne dolegliwości po doznanym udarze, starał się uzyskać zgodę na objęcie kuratelą nieletniego wówczas potomka księcia pruskiego Albrechta Fryderyka. Skomplikowana sytuacja prawna i roszczenia kolejnych książąt do udziału w pruskiej sukcesji powodowały, iż do Królewca i na inne dwory północne wielokrotnie posłowali przedstawiciele Zygmunta II Augusta (Wachowiak, Kamieński 2001: 220-221).

Szczególnie chętnie monarcha wysyłał w tym kierunku Piotra Kłoczowskiego i Jana Dymitra Solikowskiego, którzy w imieniu Jagiellona interweniowali w sprawach pruskich od 1566 roku. Wówczas to będący pod znacznym wpływem księcia meklemburskiego książę pruski Albrecht dokonał licznych zmian testamentalnych i bez wcześniejszej zgody króla Zygmunta II ustanowił nowy porządek przekazywania sukcesji w Prusach, dając w tej sprawie pierwszeństwo Janowi Albrechtowi meklemburskiemu i jego następcom. Kolejne interwencje polskich komisarzy nie przynosiły oczekiwanych skutków. Złożoność sytuacji politycznej, wyznaniowej i prawnej Prus Książęcych, Brandenburgii i Meklemburgii potęgowały rozbieżne poglądy na sprawy pruskie wewnątrz samej Rzeczypospolitej. Każdy z potencjalnych sukcesorów pruskiego lenna miał swoich zwolenników i przeciwników, którzy starali się wpływać na politykę i decyzje króla Zygmunta. Bardziej jednoznaczne decyzje wymusiła dopiero śmierć Albrechta Hohenzollerna w marcu 1568 roku. W lipcu 1569 władcą w Prusach Książęcych ogłoszono książęcego syna Albrechta Fryderyka, od którego król przyjął hołd lenny. Wówczas Jagiellon potwierdził też prawo do ewentualnej sukcesji w Prusach Joachimowi Il brandenburskiemu, jego synowi Janowi Jerzemu oraz Jerzemu Fryderykowi margrabiemu Ansbach. Akt ten został konfirmowany w marcu 1572 roku (Wachowiak, Kamieński 2001: 221-223).

Śmierć Zygmunta Augusta i niewielkie zaangażowanie Henryka Walezego sprawiły, że kwestie pruskie pojawiły się w kręgu zainteresowań polskiej dyplomacji dopiero w czasach Stefana Batorego. Panujący samodzielnie od 1569 roku książę Albrecht Fryderyk Hohenzollern nie mógł spełnić pokładanych w nim nadziei. Z powodu 
rozpoznanych u niego zaburzeń psychicznych krewni księcia podjęli działania w celu przejęcia nad nim kurateli, a co ważniejsze - administracji Prus. Szczególną aktywność w tej kwestii rozwinął Jerzy Fryderyk Hohenzollern, powołując się na swoje prawa do sukcesji pruskiej. Ostateczne decyzje nie mogły jednak zapaść bez zgody królewskiej. Nowo obrany monarcha Stefan Batory za pośrednictwem swoich posłów, Wawrzyńca Goślickiego, Tomasza Jana Drohojowskiego oraz Marcina Leśniowolskiego, starał się przedstawić możliwie wysoką cenę za poparcie określonego kandydata. Rokowania dotyczące prawa do opieki nad Albrechtem Fryderykiem i Prusami zakończyły się 22 września 1577 roku. Wówczas to dekretem królewskim kuratelę powierzono Jerzemu Fryderykowi, nadając mu ponadto prawo do używania tytułu księcia pruskiego. Akt ten uroczyście zatwierdzono 3 marca 1578 roku. Za wsparcie królewskie margrabia przekazał monarsze znaczną ilość gotówki, niezbędnej dla prowadzenia działań zbrojnych przeciw Moskwie. Ofiarował Batoremu także swoją pomoc wojskową i polityczną. Finalnie Jerzy Fryderyk sprawował władzę w Prusach do roku 1603 (Topolski 2015: 213; Wachowiak, Kamieński 2001: 224-227).

Istotnym elementem relacji dyplomatycznych z państwami niemieckimi były sprawy dynastyczne. Pozostawiwszy po sobie liczne żeńskie potomstwo, Zygmunt I starał się odpowiednimi mariażami wzmocnić dom jagielloński. Dwie spośród swoich córek wydał za książąt niemieckich, co miało być gwarantem dobrosąsiedzkich relacji, a co ważniejsze - wpływu na sejm Rzeszy, a pośrednio na dwór cesarski. Urodzona w roku 1513 Jadwiga Jagiellonka poślubiła elektora brandenburskiego Joachima II Hektora Hohenzollerna, a młodsza od niej Zofia Henryka Il księcia Brunszwiku z dynastii Welfów (Wdowiszewski 2005: 137-140; Duczmal 1996: 514-119). W obu przypadkach małżonki przeżyły swoich mężów, co powodowało konieczność zadbania o ich oprawy i utrzymanie możliwie wysokiej pozycji w zamieszkałych księstwach. Swego rodzaju "specjalistą" w kwestiach dbania o siostry polskiego króla był Stanisław Sędziwój Czarnkowski. Swoje starania w tej dziedzinie rozpoczął legacją do książąt Rzeszy jesienią 1569 roku. Wówczas jednym z ważniejszych punktów poselstwa było udzielenie wsparcia Zofii Jagiellonce w sporze z jej pasierbem Juliuszem księciem Brunszwiku i Luneburga. Kolejną legację w tej sprawie odbył Wawrzyniec Goślicki na początku roku 1572. Z podobnymi problemami zmagała się Jadwiga w Brandenburgii, gdzie jej pasierb Jan Jerzy również nie kwapił się do wypłacenia macosze należnych jej sum oprawnych, o które upominał się jeszcze długo po jej śmierci w imieniu Rzeczypospolitej Marcin Leśniowolski (Kowalska 1972: 183; Lepszy 1938: 222-224).

\section{Imperium Osmańskie oraz Chanat Krymski}

Jednym z najważniejszych kierunków polsko-litewskiej dyplomacji przez cały XVI w. było Imperium Osmańskie. W okresie zygmuntowskim udało się niemal na stałe unormować stosunki polsko-tureckie do tego stopnia, że między obiema siłami nie doszło do otwartego konfliktu. Zarówno Zygmunt I, jak i jego następca Zygmunt August prowadzili politykę zachowania neutralności między Osmanami a Europą Zachodnią. 
Do dziś zagadnienie relacji dyplomatycznych osmańsko-jagiellońskich nie zostało należycie przedstawione, głównie z braku szerokich kwerend $w$ archiwach tureckich. O tym, że był to niezwykle istotny kierunek działań polityki zagranicznej świadczyć może liczba odbytych poselstw. W ciągu ostatnich lat panowania Zygmunta Augusta do Stambułu wysłano dwie znaczne legacje Piotra Zborowskiego w $1568 \mathrm{r}$. oraz Andrzeja Taranowskiego w 1572 r. Dwa kolejne poselstwa kierowano do przedstawicieli sułtana na Węgrzech (Pajewski 1936: 29-90). Te sprawowali Jan Maciejowski, podkomorzy sandomierski, oraz sekretarz królewski Jan Woroniecki. Dodając do tego fakt niemal stałego przebywania w stolicy Osmanów nieoficjalnego agenta Joachima Strasza Odrowąża (Łąka 2006-2007), aktywność polskiej dyplomacji na tym obszarze można uznać za istotną.

Dobre relacje z Portą nie ustały po wyborze na tron Rzeczypospolitej Siedmiogrodzianina, na którym z racji posiadanego księstwa ciążył obowiązek stosunków lennych wobec sułtana. Elekcja Batorego niezwykle ucieszyła stronę turecką, gdyż skutecznie eliminowała na tym polu kandydaturę Habsburga, utrzymując równowagę sił w Europie. Jako książę Siedmiogrodu Batory nie miał szans na równorzędne stosunki z potężnym sąsiadem, obejmując jednak tron polsko-litewski, mógł zmienić ton prowadzonej dyplomacji. Na rzecz utrzymania dobrych stosunków z Turcją wpływała sytuacja geopolityczna i stałe zagrożenie ze strony Moskwy. Wzrost potęgi Iwana IV, szczególnie niebezpiecznej w przypadku zbliżenia Moskwy i Wiednia, zagrażał nie tylko Rzeczypospolitej, ale i prowadzącym wojny z Persją Osmanom. Wobec tego Turcja z zadowoleniem przyjmowała kolejne wiadomości o zwycięstwach polskiego króla, które odnosił nad Iwanem IV w Inflantach i ziemi smoleńskiej. Zmieniało to także stosunek sułtanów do Batorego, którego z czasem zaczęto traktować jak równorzędnego władcę. Nie bez znaczenia była wyspecjalizowana dyplomacja polska, która bardzo aktywnie działała na obszarze Turcji oraz Krymu.

Specyfika dworu sułtańskiego wymagała pewnej wprawy w działaniach dyplomatycznych. Z tego powodu chętnie sięgano po sprawdzonych legatów, pośród których największym doświadczeniem wyróżniał się Andrzej Taranowski. Posłując pięciokrotnie do Stambułu i na Krym, potrafił odnaleźć się w tamtejszych realiach i przy współpracy z polskimi agentami łagodzić pojawiające się zatargi. Większość problemów polsko-tureckich wynikała z uciążliwych najazdów tatarskich na tereny Rzeczypospolitej oraz wymierzonych w Turcję napadów kozackich. Utrzymywanie stałych relacji było szczególnie istotne dla Stefana Batorego, ze względu na jego związki z Siedmiogrodem, gdzie starał się zabezpieczyć przyszłość swoich bratanków, również w oparciu o przyjaźń z sułtanem (Dopierała 1986: 25-59).

\section{Księstwa Naddunajskie}

Niezmiernie niegdyś istotne relacje z Węgrami, później Siedmiogrodem, z czasem zostały zmarginalizowane. W ostatnich latach swojego panowania Zygmunt II wysłał 
tam zaledwie dwa poselstwa, kasztelana żarnowieckiego Jana Maciejowskiego oraz sekretarza królewskiego Jakuba Woronieckiego. W momencie objęcia tronu przez Batorego sprawy siedmiogrodzkie przybrały charakter wewnętrzny, co skutkowało brakiem konieczności realizowania osobnych legacji w tym kierunku. Zdecydowanie aktywniejsza była polityka prowadzona względem Mołdawii i Wołoszczyzny. Aby zapewnić wpływy Rzeczypospolitej na tych terenach, oprócz działań zbrojnych przedsięwzięto cztery misje dyplomatyczne, zwykle związane ze zmianami na tronie hospodarskim (Pajewski 1932: 213-238).

\section{Moskwa}

Stałym obszarem działań polskiej dyplomacji, niezależnie od osoby monarchy, była Moskwa. Świadczy o tym aż 11 misji poselskich, które zgodnie z zasadami unii z 1569 roku sprawowali w większości Litwini. Wojny ostatniego Jagiellona z Wielkim Księstwem Moskiewskim, prowadzone z przerwami w latach 1563-1569, nie zakończyły się sukcesem strony polsko-litewskiej ani na kierunku północnym, ani wschodnim. Działania dyplomatyczne, które blokowały dalsze walki litewsko-rosyjskie, okazały się doskonałym sposobem na przeczekanie trudnej sytuacji. Już na początku lat 70. korzystnie dla Rzeczypospolitej zmieniła się geopolityka. Sprzymierzony władca na tronie szwedzkim, przyjazne relacje z Turcją i niemal rozbity postanowieniami kongresu szczecińskiego sojusz Moskwy z Danią spowodował osamotnienie polityczne Iwana IV. Mimo to Zygmunt August nie wyraził zgody na sułtańskie propozycje wspólnego rozgromienia Moskwy (Cynarski 2004: 185-188).

Już w lipcu 1571 poselstwo pod przywództwem Michała Haraburdy pojawiło się w Moskwie, gdzie próbowano odwieść Iwana IV od wspierana Magnusa księcia duńskiego. W okresie pierwszego bezkrólewia została zainicjowana przez Radę Wielkiego Księstwa Litewskiego legacja do Moskwy, celem blokowania kandydatury Fiodora Iwanowicza na tron wielkoksiążęcy, aż do momentu wyboru nowego króla (Fłoria 1971: 85-90). Nowa koncepcja prowadzenia polityki zagranicznej pojawiła się wraz z objęciem tronu przez Batorego. Dotyczyło to szczególnie działań względem wschodniego sąsiada. Dostrzegano bowiem konieczność przeciwstawienia się coraz silniejszej Moskwie, zagrażającej interesom Rzeczypospolitej na wschodzie i północy. Znaczne zaangażowanie wykazywał w tej kwestii sam król. Zdawał sobie bowiem sprawę, że ewentualne nadzieje na przyszłe oswobodzenie Węgier i upomnienie się o swoje prawa do tych ziem mogą zostać zrealizowane jedynie poprzez zabezpieczenie wschodnich granic państwa polsko-litewskiego (Boratyński 1903: 30-33). Prowadzone w latach 1577-1582 walki Batorego z Moskwą o Inflanty i ziemię połocką odbywały się nie tylko za pomocą oręża. Istotną rolę odgrywała tam także dyplomacja, której efektem było zorganizowanie poselstw, mających na celu wypracowanie korzystnych traktatów pokojowych. W sierpniu 1580 roku Piotr Kłoczowski i Jan Tomasz Drohojowski udali się, jako komisarze króla Stefana Batorego, na pertraktacje do Wieliża, gdzie miały być ustalone warunki poddania miasta i twierdzy (Żelewski 1967: 53). 
Kolejne sukcesy doprowadziły do zawarcia korzystnego dla strony polsko-litewskiej traktatu w Jamie Zapolskim, który negocjowali wojewoda bracławski Janusz Zbaraski, marszałek nadworny litewski Albrecht Radziwiłł oraz pisarz wielki litewski Michał Haraburda. W relacjach z Moskwą zdecydowanie najważniejszą rolę odgrywał właśnie Haraburda, który kontynuował swoją misję dyplomatyczną w Rosji w latach 1584-1586, dążąc do zawarcia wieczystego pokoju między Rzecząpospolitą i Rosją (Lepszy 1960-1961: 289-290). Po zakończeniu wojen z Iwanem IV nagrodzony został starostwem świsłockim. Unormowanie relacji z Rosją, nieco przychylniejszą Rzeczypospolitej po śmierci Iwana IV, dawało możliwość zwrócenia uwagi i sił w stronę turecką. Tej kampanii nie podjęto jednak ze względu na śmierć króla Stefana.

\section{Rzym}

Odrębnym tematem są z całą pewnością legacje do Wiecznego Miasta, których w omawianym okresie zrealizowano dziewięć. Trzy z nich miały charakter uroczystych poselstw obediencyjnych, Pawła Uchańskiego w 1579, Andrzeja Batorego w 1583 i Jana Dymitra Solikowskiego w 1586 roku. Szczególnie istotne wydaje się poselstwo Andrzeja Batorego, królewskiego bratanka, który z Rzymu przywiózł paliusz kardynalski i wstępny plan ligi antytureckiej pod wodzą Stefana Batorego (Horn 2010: 70-95). Pozostałe misje miały charakter bardziej "doraźny”. Jesienią 1576 jako osobisty poseł Stefana Batorego dotarł do Rzymu sekretarz królewski, cysters Jan Grzymała Zamoyski, przekazując niejawne listy monarchy na ręce papieża Grzegorza XIII. Można przypuszczać, że wiązały się one z uprawomocnienia wyboru Siedmiogrodzianina na tronie Rzeczypospolitej wobec przeprowadzonej podwójnej elekcji. Ponowny wyjazd Zamoyskiego do Rzymu w 1577 roku związany był z opóźniającym się poselstwem obediencyjnym Pawła Uchańskiego. Celem misji było także pozyskanie włoskich profesorów do nowo powstałego gimnazjum królewskiego w Krakowie oraz zezwolenia nadawania tam tytułów doktorskich (Banaszak 1975: 112-117). Ostatnia zawarta w wykazie misja rzymska, realizowana przez Stanisława Reszkę i Andrzeja Batorego, służyła celom bieżącej polityki i umacnianiu dobrego wizerunku rodziny Batorych wśród władców chrześcijańskich.

\section{Dwór cesarski}

Obok papieskiego dwór cesarski charakteryzował się znaczną siłą przyciągania dyplomatów z całej Europy. Stanowiąc jedno z centrów chrześcijańskiego świata, stolica cesarstwa była miejscem prowadzenia nieustannej polityki. Nie brakowało tam także niemal stałych przedstawicieli dynastii Jagiellonów, których kontakty z domem Habsburgów były bardzo ścisłe i naturalne. Ciągła obecność nie oznaczała jednak braku innych poselstw „doraźnych", co nie tylko pozytywnie wpływało na przepływ informacji, ale także zabezpieczało przed zbytnim zbliżeniem się posła do cesarskiego dworu. Przykładem było poselstwo Adama Konarskiego, które zostało zorganizowane w celu 
doprowadzenia do ugody między cesarzem Maksymilianem II a Janem Zygmuntem Zapolyą, w czasie gdy na dworze cesarskim przebywał już prepozyt gnieźnieński Łukasz Podoski. Zmiany w organizowaniu kontaktów w cesarzem zaszły wraz ze śmiercią ostatniego Jagiellona. Zakończyła się wówczas klasyczna dyplomacja dynastyczna, charakteryzująca się stałymi kontaktami ze strategicznymi ośrodkami (Rzym, Wiedeń, Stambuł). W ramach 9 odbytych na przestrzeni dwóch dekad legacji należy wyróżnić te, które wiązały się z kwestiami elekcyjnymi, oraz te, które wynikały z bieżących potrzeb politycznych. Do pierwszej grupy należy zaliczyć poselstwa Olbrachta Łaskiego oraz Jana Dymitra Solikowskiego wraz z Janem Krotskim w roku 1576, czy Jerzego Radziwiłła i Mikołaja Firleja latem 1589 (Wójcik 1982: 15-26).

Inny charakter miała choćby legacja Łukasza Podoskiego do cesarza na przełomie 1578 i 1579 roku, której celem były wstępne starania powołania ligi antytureckiej. Ponadto świeżo wybrany król, korzystając z autorytetu Rzeczypospolitej, starał się także wywrzeć presję na Habsburgu, by ten oddał mu część zabranych jeszcze przez jego ojca ziem węgierskich. W czerwcu 1580 roku Podoski ponownie posłował do Pragi, gdyż król nie był zadowolony z odpowiedzi i stanowiska cesarza (Żelewski 1983: 171-173). Misje dyplomatyczne kierowane na dwór cesarski generalnie charakteryzowały się dużą dozą doraźności, stanowiącej coraz częstszy element polskiej dyplomacji.

\section{Pozostałe misje dyplomatyczne}

To, co uwidacznia powyższe zestawienie to sporadyczność organizowania misji poselskich do państw spoza najbliższego sąsiedzkiego kręgu. Do takich należało poselstwo Krzysztofa Głoskowskiego, sekretarza królewskiego, do Republiki Zjednoczonych Prowincji, gdzie w imieniu Stefana Batorego starał się interweniować w sprawie niepodległości Niderlandów wobec Filipa II Habsburga (Boratyńsk 1908: 322-334). Do samego Filipa Il posłano zaledwie jedną legację, którą odprawił latem 1585 Stanisław Sobocki. Celem poselstwa było prawdopodobnie zainteresowanie hiszpańskiego Habsburga planami powołania wielkiej ligi antytureckiej, w której budowanie w ostatnich latach życia zaangażował się król Stefan (Dembiński 1999: 354-355).

Na marginesie aktywności dyplomatycznej pozostały także takie kierunki, jak Anglia czy Francja. Pod znakiem zapytania pozostają wciąż rzeczywiste powody wyprawy do Anglii wojewody sieradzkiego Olbrachta Łaskiego. Zdaniem Romana Żelewskiego misję inicjował król Stefan Batory, chcąc tym samym przeciwdziałać niebezpiecznym skutkom zbliżenia Anglii z Moskwą, której posłowie przebywali w tym samym czasie na dworze królowej Elżbiety (Żelewski 1973: 248-250). Ciekawym elementem relacji z Anglikami były prowadzone w Elblągu negocjacje z Angielską Kompanią Wschodnią. W związku z problemami gdańskimi, które istotne wpływały na ekonomię Rzeczypospolitej, król starał się poprzez swoich wysłanników, m.in. Piotra Potulickiego, wojewody brzesko-kujawskiego, zbadać sprawę rywalizacji Elbląga z Gdańskiem o utworzenie 
na terenie któregoś z miast stałej siedziby Kompani Wschodniej. Finalnie zwycięski z tej rywalizacji wyszedł Elbląg, przez blisko pół wieku będąc jednym z bardzo istotnych portów bałtyckich (Biblioteka Jagiellońska, rękopis nr 44 - Historya Dyplomatyczna polsko-angielska wraz a Annexami ab Anno 1280 ad Annum 1731: 152-179).

Aktywność dyplomatyczna skierowana na Francję także była niewielka. W ciągu dwóch dekad wysłano tam zaledwie dwa poselstwa. Pierwsze oficjalne poselstwo miało na celu powiadomić Henryka Walezego o jego zwycięskiej elekcji. Przedstawiciele Rzeczypospolitej mieli także za zadanie wypracować zasady przejęcia władzy w nowej ojczyźnie przez Walezego oraz przygotować treść wzajemnych umów polsko-francuskich. Zaledwie półtora roku później posłano drugą legację, tym razem mającą na celu przekonanie króla do powrotu na łono Rzeczypospolitej.

\section{Zakończenie}

Omawiając poszczególne kierunki polskich legacji, można pokusić się o kilka uwag generalnych. Pierwszą zauważalną tendencją jest systematyczne zawężanie pola aktywności dyplomatycznej niemal wyłącznie do państw ościennych. Wynikało to rzecz jasna z bieżących potrzeb i koncepcji politycznych kolejnych władców. Przełomem w wielu obszarach wydaje się śmierć ostatniego Jagiellona, kończąca pewną stabilizację, wynikającą z prowadzonej przez wiele dekad polityki dynastycznej. Trzykrotne zmiany na tronie Rzeczypospolitej również odcisnęły swoje piętno na działaniach dyplomacji. Odzwierciedla to najlepiej niemal całkowity brak wysyłanych poselstw przez Henryka Walezego, utrzymującego kontakty z obcymi państwa za pomocą zewnętrznych pośredników. Początek panowania Stefana Batorego to niemal całkowite skupienie się na działaniach wojennych i dostosowywanie dyplomacji do tychże potrzeb. Wydaje się to zrozumiałe, zwłaszcza w kontekście geopolityki. Pewne zmiany pojawiły się w drugiej połowie rządów Batorego, gdzie plany powołania ligi antytureckiej uaktywniły działania międzynarodowe. Można założyć, że potencjalne dłuższe panowanie Siedmiogrodzianina na polskim tronie wiązałoby się z dalszym rozwojem kierunków i aktywności dyplomatycznych Rzeczypospolitej.

Pierwsze dekady funkcjonowania zjednoczonego państwa polsko-litewskiego wskazują na długotrwałość pewnych procesów, w tym kształtowania się koncepcji prowadzenia aktywnej polityki międzynarodowej. Powyższe zestawienie i jego analiza z całą pewnością nie wyczerpuje tematu funkcjonowania dyplomacji i dyplomatów na przestrzeni wspomnianych dwóch dekad. Wielce prawdopodobne, iż nie udało się w tym miejscu zestawić wszystkich misji poselskich, jakie miały miejsce w omawianym okresie, co wynika z poważnego rozproszenia materiału źródłowego i licznych trudnościach w jego interpretacji. Mam jednak nadzieję, że niniejszy tekst wskazał pewne tendencje, którymi cechowała się aktywność dyplomacji Rzeczypospolitej w latach 1569-1589, czyli od powołania do życia Rzeczypospolitej Obojga Narodów, po przejęcie władzy w niej nowej dynastii - Wazów. 


\section{Bibliografia}

Źródła:

Abrahamowicz Z., 1959, Katalog dokumentów tureckich. Dokumenty do dziejów Polski i krajów ościennych w latach 1544-1672, Warszawa.

Archiwum Główne Akt Dawnych w Warszawie, Metryka Koronna, Księgi Wpisów (Libri Inscriptionum) nr 106-135.

Archiwum Główne Akt Dawnych w Warszawie, Metryka Koronna, Księgi Poselstw (Libri Legationum), nr 19, 20, 21, 25, 26, 27, 28, 41.

Barycz H., 1939, L. Górecki, Kronika z czasów króla Stefana Batorego 1575-1582, Kraków.

Biblioteka Jagiellońska, rękopis nr 44 - Historya Dyplomatyczna polsko-angielska wraz z Annexami ab Anno 1280 ad Annum 1731.

Janicki I., 1872, Akta poselski i korespondencje Franciszka Krasińskiego 1558-1576, Kraków.

Kalinowska J.A., 1992, Z dworu Stanisława Hozjusza. Listy Stanisława Reszki do Marcina Kromera 1568-1582, Olsztyn.

Krawczuk W. (red.), 2004, Sumariusz Metryki Koronnej. Seria Nowa. Tom III, Księga wpisów podkanclerzego Wojciecha Baranowskiego MK 134 z Archiwum Głównego Akt Dawnych w Warszawie lata 1587-V 1588, Kraków.

Kutrzeba S., Semkowicz W., 1932, Akta unji Polski z Litwq 1385-1791, Kraków.

Pawiński A., 1882, Akta metryki koronnej co ważniejsze z czasów Stefana Batorego 1576-1586 [w:] Źródła dziejowe, t. XI, Warszawa.

Sobieski W., 1904, Archiwum Jana Zamoyskiego kanclerza i hetmana wielkiego koronnego, t. I: 1553-1579, Warszawa.

Sokół G., Kot A., Spyrka G., Krawczuk W. (red.), 2001, Sumariusz Metryki Koronnej. Seria nowa. Tom II, Księga wpisów kanclerza Jana Zamoyskiego MK 133 z Archiwum Głównego Akt Dawnych w Warszawie. Dokumenty z czasów panowania Zygmunt III Wazy 1587-1595, Kraków.

Turowski J., 1858, Herby rycerstwa polskiego przez Bartosza Paprockiego zebrane i wydane r. p. 1584, Kraków.

Wierzbowski T. (ed.), 1919, Matricularum Regni Poloniae Sumaria, Pars 5. Sigismundi Augusti regis tempora complectens (1548-1572), Volumen 1. Acta cancellariorum (1548-1572), Volumen 2. Acta vicecancellariorum (1548-1572), Varsoviae.

Woźniakowa M., 1999, Matricularum, Pars. 6. Henrici Valesii regis tempora complectens (1573-1574), Varsoviae.

Opracowania:

Banaszak M., 1975, Z dziejów dyplomacji watykańskiej. Część druga, dzieje poselstw polskich, Warszawa.

Baranowski B., 1948, Dzierżek Krzysztof [w:] Polski słownik biograficzny, t. VI, Kraków.

Barycz H., 1970, Kromer Marcin [w:] Polski słownik biograficzny, t. XV, Wrocław.

Biskup M., 1980, Historia dyplomacji polskiej, t. 1, Połowa X w. - 1572, Warszawa.

Bodniak S., 1929, Kongres Szczeciński na tle bałtyckiej polityki polskiej, Kraków.

Bodniak S., 1948, Działyński Michał [w:] Polski słownik biograficzny, t. Vl, Kraków.

Boratyński L., 1908, Stefan Batory, Hanza i powstanie Niderlandów, „Przegląd Historyczny”, t. 6. 
Boratyński L., 1903, Stefan Batory i plan ligi przeciw Turkom (1576-1584), Kraków.

Chłapowski K., Ciara S., Kądziela Ł. i inni, 1992, Urzędnicy centralni i nadworni polski XIV-XVIII wieku. Spisy. Gąsiorowski A. (red.) Urzędnicy dawnej Rzeczypospolitej XII-XVIII wieku. Spisy, Kórnik.

Chłapowski K., Falniowska-Gradowska A., 1993, Urzędnicy województwa sandomierskiego XVI-XVIII w. Spisy, Gąsiorowski A. (red.) Urzędnicy dawnej Rzeczypospolitej XII-XVIII wieku. Spisy, Kórnik.

Chodynicki K., 1936, Broniewski Prokop [w:] Polski słownik biograficzny, t. II, Kraków.

Cynarski S., 2004, Zygmunt II August, Wrocław.

Dembiński P., 1999, Sobocki Stanisław [w:] Polski słownik biograficzny, t. XXXIX, Warszawa-Kraków.

Dopierała K., 1986, Stosunki dyplomatyczne Polski z Turcją za Stefana Batorego, Warszawa.

Duczmal M., 1996, Jagiellonowie. Leksykon biograficzny, Kraków-Poznań.

Dziubiński A., 2005, Stosunki dyplomatyczne polsko-tureckie w latach 1500-1572 w kontekście międzynarodowym, Wrocław.

Fłoria B.N., 1971, Rosyjska kandydatura na tron polski u schyłku XVI wieku, „Odrodzenie i Reformacja”, t. XVI, Warszawa.

Gmiterek H., 2000, Sobieski Marek [w:] Polski słownik biograficzny, t. XXXIX, Warszawa-Kraków.

Gmiterek H., Szczygieł R., 1992, Urzędnicy województwa bełskiego i ziemi chełmskiej XIV-XVIII wieku. Spisy, Gąsiorowski A. (red.) Urzędnicy dawnej Rzeczypospolitej XII-XVIII wieku. Spisy, Kórnik.

Henning H.H., 1987, Dyplomacja bez listów uwierzytelniających. Polityka zagraniczna Adama Jerzego Czartoryskiego 1830-1840, Warszawa.

Horn I., 2010, Andrzej Batory, Warszawa.

Kadzik D., 2016, Spis dworzan zmarłego króla polskiego Stefana Batorego „„Zeszyty Naukowe Uniwersytetu Jagiellońskiego. Prace Historyczne" nr 143, z. 1.

Kalinowska A.J., 1988, Reszka Stanisław [w:] Polski słownik biograficzny, t. XXXI, Wrocław.

Kaniewska I., 1996, Sienieński Jan [w:] Polski słownik biograficzny t. XXXVII, Warszawa-Kraków.

Kłaczewski W., Urban W., 1991, Urzędnicy województwa lubelskiego XVI-XVIII wieku. Spisy, Gąsiorowski A. (red.) Urzędnicy dawnej Rzeczypospolitej XII-XVIII wieku. Spisy, Kórnik.

Kot S., 1928, Z dziejów propagandy polskiej w wieku XVI. Dyplomaci polscy w Neapolu, Kraków.

Kotarski E., Kumor B., 2000-2001, Solikowski Jan Dymitr [w:] Polski słownik biograficzny, t. XL, Warszawa-Kraków.

Kowalska H., 1972, Leśniowolski Marcin, [w:] Polski słownik biograficzny, t. XVII, Wrocław.

Kowalska H., 1975, Mielecki Mikołaj [w:] Polski słownik biograficzny, t. XX, Wrocław.

Kowalska H., 1996, Sienieński Jan [w:] Polski słownik biograficzny t. XXXVII, Warszawa-Kraków.

Leitgeber S., 1984-1985, Potulicki Piotr [w:] Polski słownik biograficzny, t. XXVIII, Wrocław.

Lepszy K., 1938, Stanisław Sędziwój Czarnkowski [w:] Polski słownik biograficzny, t. VI, Kraków.

Lepszy K., 1939-1946, Drohojowski Jan Tomasz [w:] Polski słownik biograficzny, t. V, Kraków.

Lepszy K., 1946, Dominium Maris Baltici Zygmunta Augusta , „Nauka i Sztuka”, t. 4, nr 9,

Lepszy K., 1948-1958, Firlej Mikołaj [w:] Polski słownik biograficzny, t. VII, Kraków.

Lepszy K., 1960-1961, Haraburda Michał [w:] Polski słownik biograficzny, t. IX, Wrocław.

Lulewicz H., 1981, Pietkiewicz Jerzy [w:] Polski słownik biograficzny, t. XXVI, Warszawa.

Lulewicz H., 1987, Radziwiłł Mikołaj Krzysztof zw. Sierotka [w:] Polski słownik biograficzny, t. XXX, Wrocław. 
Łąka J.S., 2006-2007, Strasz Joachim h. Odrowąż [w:] Polski słownik biograficzny, t. XLIV, Kraków. Maniewska D., 1960, Goślicki Wawrzyniec [w:] Polski słownik biograficzny, t. IX, Wrocław.

Mikulski K., Rachuba A., 1994, Urzędnicy inflanccy XVI-XVIII wieku. Spisy, Gąsiorowski A. (red.) Urzędnicy dawnej Rzeczypospolitej XII-XVIII wieku. Spisy, Kórnik.

Mikulski K., Staniek W., 1990, Urzędnicy kujawscy i dobrzyńscy XVI-XVIII w. Spisy, Gąsiorowski A. (red.) Urzędnicy dawnej Rzeczypospolitej XII-XVIII wieku. Spisy, Kórnik.

Nowak-Kiełbikowa M., Bułhak H., Wójcik Z. (red.), 1993, Studia z dziejów Europy, Polski i Ślaska. Prace ofiarowane Józefowi Andrzejowi Gierowskiemu pod red. K. Matwijowskiego, Wrocław 1992, Z dziejów polityki i dyplomacji polskiej. Studia poświęcone pamięci Edwarda hr. Raczyńskiego, Prezydenta Rzeczypospolitej Polskiej na Wychodźstwie, Warszawa.

Nowek Z.H. (red.), 1992, Balticum. Studia z dziejów polityki, gospodarki i kultury XII-XVII wieku . Ofiarowane Marianowi Biskupowi w siedemdziesiątą rocznicę urodzin, Toruń.

Odyniec W. (1982) Polskie dominium maris Baltici. Zagadnienia geograficzne, ekonomiczne i społeczne X-XVIII wieku, Warszawa.

Opaliński E., Żerek-Kleszcz H., 1993 Urzędnicy województw łęczyckiego i sieradzkiego XVI-XVIII wieku. Spisy, Gąsiorowski A. (red.) Urzędnicy dawnej Rzeczypospolitej XII-XVIII wieku. Spisy, Kórnik.

Pajewski J., 1932, Węgierka polityka Polski w połowie XVI wieku (1540-1571), Kraków.

Pajewski J., 1936, Legacja Piotra Zborowskiego do Turcji w 1568 r. Materiały do historii stosunków polsko-tureckich za panowania Zygmunta Augusta , ,Rocznik Orientalistyczny", t. 12.

Piwnicki G, Klein A., 2012, Polska polityka morska za panowania ostatnich dwóch Jagiellonów ijej pokłosie „Studia Gdańskie", t. 31.

Przyboś A., 1970, Kryski Stanisław [w:] Polski słownik biograficzny, t. XV, Wrocław.

Przyboś A., Żelewski R., 1959, Dyplomaci w dawnych czasach. Relacje staropolskie z XVI-XVIII stulecia, Kraków.

Przyboś K. (1987) Urzędnicy województwa ruskiego XIV-XVIII w., Wrocław.

Rocznik Służby Zagranicznej Rzeczypospolitej Polskiej według stanu na 1 kwietnia 1938, 1938, Warszawa.

Samsonowicz H., 1982, Gdańsk a poczynania morskie Zygmunta Augusta [w:] Historia Gdańska, t. II (1454-1655), Gdańsk.

Sułkowska-Kurasiowa I., Wejcherowa J., 1968, Księgi poselskie (Libri Legationum) Metryki Koronnej, "Archeion" XLVIII.

Szczotka S., 1949, Filipowski Hieronim [w:] Polski słownik biograficzny, t. Vl, Kraków.

Topolski J., 2015, Rzeczpospolita Obojga Narodów 1501-1795, Poznań.

Wachowiak B., Kamieński A. (red.), 2001, Historia Prus, narodziny-mocarstwo-obumieranie. Tom I Dzieje Brandenburgii - Prus na progu czasów nowożytnych (1500-1701), Poznań.

Wdowiszewski Z., 2005, Genealogia Jagiellonów i Domu Wazów w Polsce. Kraków.

Wijaczka J. (1998) Stosunki dyplomatyczne Polski z Rzeszą Niemiecka w czasach panowania cesarza Karola V (1519-1556), Kielce.

Wojtyska H., 1977, Papiestwo - Polska. Dyplomacja, Lublin.

Wójcik Z., 1982, Historia dyplomacji polskiej, t. II, 1572-1795, Warszawa.

Ziemlewska A., 2008, Ryga w Rzeczypospolitej polsko-litewskiej w latach 1581-1621, Toruń.

Żelewski R., 1960, Herburt Jan [w:] Polski słownik biograficzny, t. IX, Wrocław.

Żelewski R., 1967, Kłoczowski (Kłoczewski) Piotr [w:] Polski słownik biograficzny, t. XIII, Wrocław. 
Żelewski R., 1967-1968, Konarski Adam [w:] Polski słownik biograficzny, Wrocław. Żelewski R., 1970, Krotoski Jan [w:] Polski słownik biograficzny, t. XV, Wrocław.

Żelewski R., 1973, Łaski Olbracht [w:] Polski słownik biograficzny, t. XVIII, Wrocław.

Żelewski R., 1983, Podoski Łukasz [w:] Polski słownik biograficzny, t. XXVII, Wrocław.

Żelewski R., 1985, Proński (Pruński) Aleksander [w:] Polski słownik biograficzny, t. XXVIII, Wrocław. 